\title{
Organic petrography, Rock-Eval pyrolysis and biomarker geochemistry of Maastrichtian Gombe Formation, Gongola Basin, Nigeria
}

\author{
Ayoola Y. Jimoh ${ }^{1}$. Olusola J. Ojo ${ }^{2}$ (I) . Samuel O. Akande ${ }^{3}$
}

Received: 18 February 2019 / Accepted: 23 August 2019 / Published online: 31 August 2019

(c) The Author(s) 2019

\begin{abstract}
The Maastrichtian Gombe Formation is located within one of the inland basins of Nigeria (Gongola Basin). Surface and borehole samples of coal and interbedded shale of this formation were evaluated to determine the organic matter richness, quality, maturity, source and depositional environment through organic geochemical techniques such as total organic carbon (TOC) determination, Rock-Eval pyrolysis, chromatography and organic petrography. The genetic potential and average TOC value of the coals, shales and coaly shales are $38.03 \mathrm{wt} \%, 3.14 \mathrm{wt} \%$ and $12.1 \mathrm{wt} \%$, respectively, indicating moderate-to-good source potential. HIs are less than $200 \mathrm{mgHC} / \mathrm{gTOC}$ for all the samples indicating Type III kerogen for most of the samples (gas prone) and plant contributions from terrestrial sources. The source rocks were characterized by high molecular weight $n$-alkanes which range from $\mathrm{C}_{10}-\mathrm{C}_{41}$ in the coals and $\mathrm{C}_{9}-\mathrm{C}_{41}$ in the shales. The $n$-alkanes distributions in the coals maximize at $\mathrm{C}_{29}$ indicating terrestrial sourced organic matter, while the shales maximize at $\mathrm{C}_{16}$ and $\mathrm{C}_{29}$ indicating mixed sources. $\mathrm{Pr} /$ $\mathrm{Ph}$ of the coals and shales ranges from (2.15-3.51) to (0.95-2.37), respectively, suggesting fluvio-deltaic deltaic and coastal swamp depositional environments. The predominance of pristane over phytane suggests humic origin of the organic matter. The sterane/hopane values $(<0.6)$ indicate incorporation of bacterial inputs commonly associated with terrigenous organic matter in the coals. The CPI is greater than unity, $T_{\max }$ is generally $<435^{\circ} \mathrm{C}$ and vitrinite reflectance less than 0.55 Ro for most of the samples and suggest the samples are of low maturity status to expel liquid hydrocarbon.
\end{abstract}

Keywords Humic $\cdot$ Phytane $\cdot$ Maastrichtian $\cdot$ Kerogen

\section{Introduction}

The assessments of hydrocarbon accumulation in a petroleum system are subject to accurate characterization of oil source potential through various analytical techniques such as pyrolysis, elemental, chromatography and spectroscopy. Hydrocarbon prospectivity and research are still very active in the all the Cretaceous basins in Nigeria including the Northern Benue Trough (Fig. 1) in line with the

Olusola J. Ojo

olusola.ojo@fuoye.edu.ng

1 Department of Geology and Mineral Sciences, Kwara State University, Malete, Nigeria

2 Department of Geology, Federal University Oye-Ekiti, Oye-Ekiti, Nigeria

3 Department of Geology and Mineral Sciences, University of Ilorin, Ilorin, Nigeria
Government extant policy of increasing the hydrocarbon reserve in the country. The investigated source rock interval of the Maastrichtian Gombe Formation is located at the Maiganga coal mine, near Gombe, Gongola Basin, Nigeria. Previous workers in the study area (Onoduku 2013; Jimoh and Ojo 2016) have applied preliminary organic geochemical screening methods such as TOC and Rock-Eval pyrolysis to characterize the source rock potential in the study area, and due to limitation of these techniques, a further probe was considered necessary. Also, there are no detailed organic geochemical investigations on the coal and shaly source rocks in respect of biomarker characterization. Hence, the palaeodepositional environments, source, type and maturity of the organic matter in the source beds were investigated in this study based on Rock-Eval pyrolysis and biomarker techniques. 


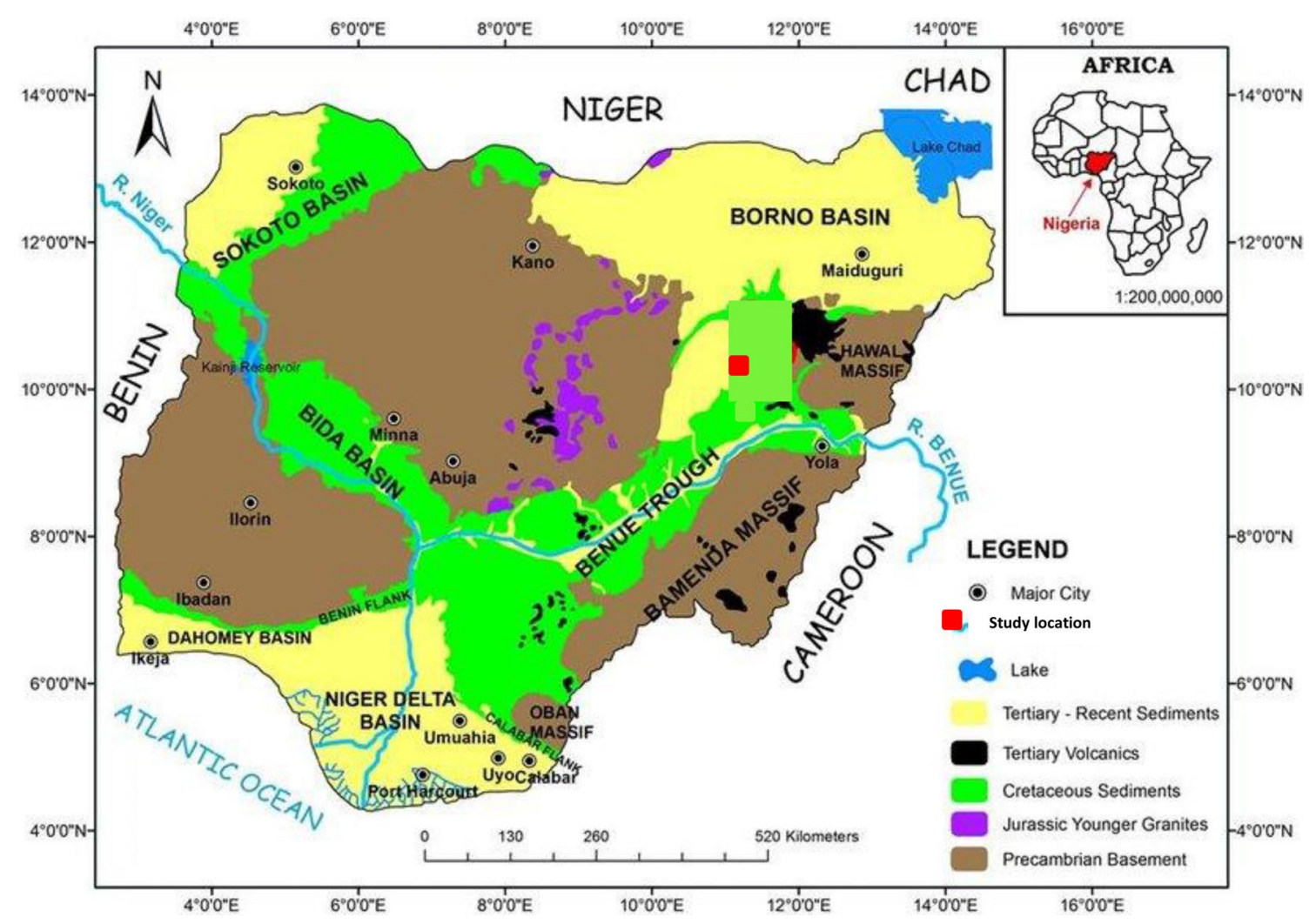

Fig. 1 Geological map of Nigeria showing the Basement Complex, sedimentary basins and the study location (Northern Benue Trough). Modified after Lar et al. (2018)

\section{Geological setting and stratigraphy}

The Benue Trough is one of the inland sedimentary basins of Nigeria formed by a rifting process (Olade 1975). The trough trends structurally in NNE-SSW direction and extends up to $800 \mathrm{~km}$ in length and $150 \mathrm{~km}$ in width (Fig. 1). The sediment fill is more than $6000 \mathrm{~m}$ of Cretaceous-Tertiary age, and those predating the mid-Santonian have been deformed, faulted and uplifted in several places (Benkhelil 1989). The Benue Trough and its peculiar structural styles (Fig. 2) are believed to be vestiges of the fragmentations and the separation of South America from Africa in the Carboniferous and opening of the South Atlantic through the process of Sea floor spreading consequent to continental up-doming and rifting (Wright 1968; Olade 1975). The Trough is partitioned into southern, central and northern section (Fig. 1). The northern section is further subdivided into Gongola and Yola basins. The stratigraphy of the Gongola Basin consists of the basement rocks, Albian Bima Formation (feldspathic sandstones), Cenomanian Yolde Formation (sandstones, shales and limestones), Turonian Pindiga Formation (shales and fossiliferous limestones), Maastrichtian Gombe Formation (sandstones, siltstones, shales, ironstones and coal seams), Tertiary Kerri-Kerri Formation (sandstones) and the alluvium (Whiteman 1982) (Fig. 3). At Maiganga, the exposed part of the mine was logged and sampled. The lithologic succession consists of about $35 \mathrm{~m}$ thick coarsening upward section with the basal part made up of coal and shale interbeds, while the upper part consists of siltstone and sandstone (Figs. 3, 4). The coal and interbedded shale at phases I and II of the mine appear most prospective source rock facies in the formation and were evaluated with respect to their hydrocarbon source rock potential. 


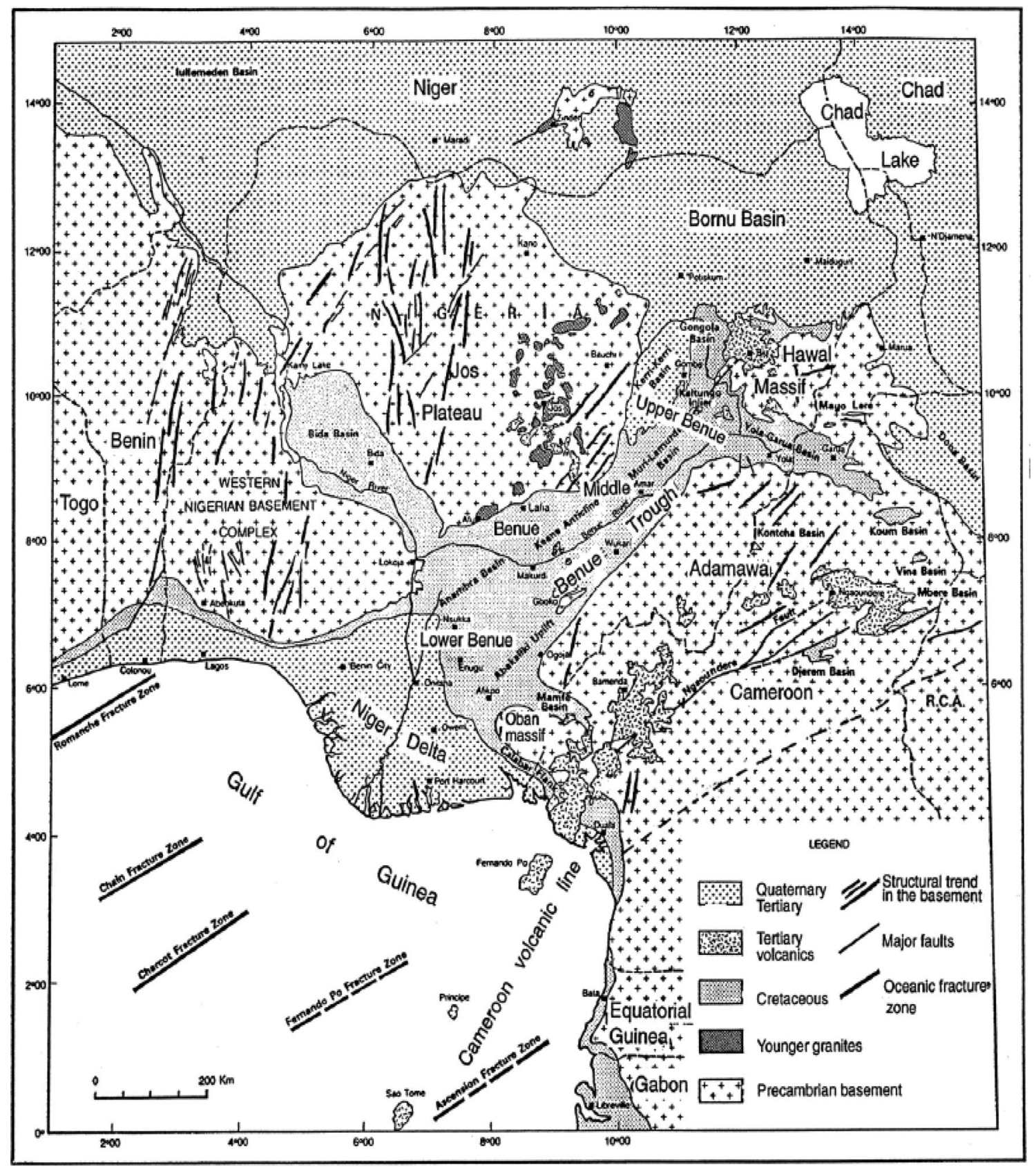

Fig. 2 Geological map of the Benue Trough. The traces of the equatorial fracture zones are indicated. After Odebode (2010)

\section{Methodology}

Sampling and logging was carried out at phases I and II of the exposed part of the mine (Figs. 4, 5) based on vertical and lateral variation of the facies. A borehole was also sampled and logged to determine any variation in organic matter preservation with respect to TOC and $S 1$ with the surface shale samples and to also confirm if there is weathering or impurities compared to the surface cuttings (Fig. 6). The coal seams were divided into seams $\mathrm{A}$ and B. Seam A was further divided into A1, A2 and A3. The coals seams and shaly intervals have varying 
Fig. 3 Stratigraphy of northern Benue Trough. Modified after Abubakar et al. (2006)

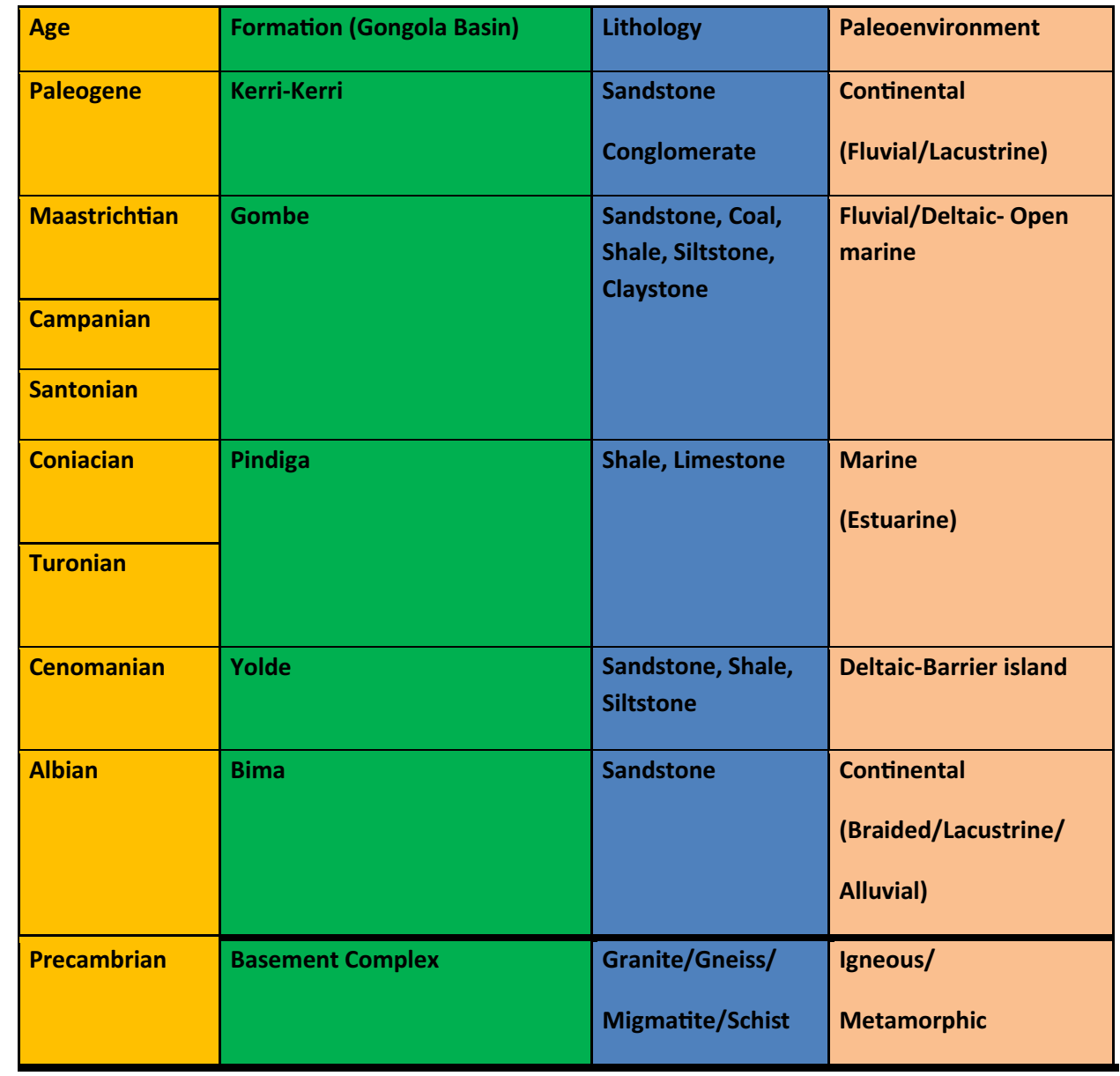

thickness in the two phases. At phase I, the coal seam B was sampled at $0.5 \mathrm{~m}$, the shale at $0.3 \mathrm{~m}$ in order to have a representative samples across the section and to acquire all the geologic details in the section. At phase II, seam B coal and shale was sampled at $0.4 \mathrm{~m}$ and $0.3 \mathrm{~m}$, respectively. Only three shale samples from the borehole were analysed. The samples were selected and subjected to various organic geochemical techniques such as TOC, Rock-Eval pyrolysis, Soxhlet extraction, gas chromatography, medium performance liquid chromatography and gas chromatography-mass spectroscopy. All the analyses were carried out at Stratochem Laboratory, Canada.

A total of twenty-nine samples (26 surface cuttings and 3 borehole samples) consisting of coal, coaly shale and shale were pulverized and weighed. Hydrochloric acid was added to the weighed samples to remove carbonates and subjected to TOC screening using LECO C230 analyser. The free hydrocarbon $(S 1)$, hydrocarbon generated by thermal cracking of the kerogen $(S 2)$ and the maximum temperature of the kerogen decomposition $\left(T_{\max }\right)$ were determined by Rock-Eval 6 instrument. Other parameters such as production index (PI), hydrogen index (HI) and genetic potential (GP) were derived from Rock to Eval pyrolysis data. Seven samples were extracted by Soxhlet method to obtain the extractable organic matter (EOM). Fresh samples were pulverized and weighed; each sample was placed in a thimble, dichloromethane and methanol was added to a conical flask in ratio 93:7. The thimble was placed in the Soxhlet apparatus and the samples extracted for seventy-two hours (72 h) after which the solvent was evaporated.

The extracts were separated into saturate, aromatic and the polar fraction by medium performance liquid chromatography containing thermally deactivated silica, in which the main column of activated silica is the stationary phase 


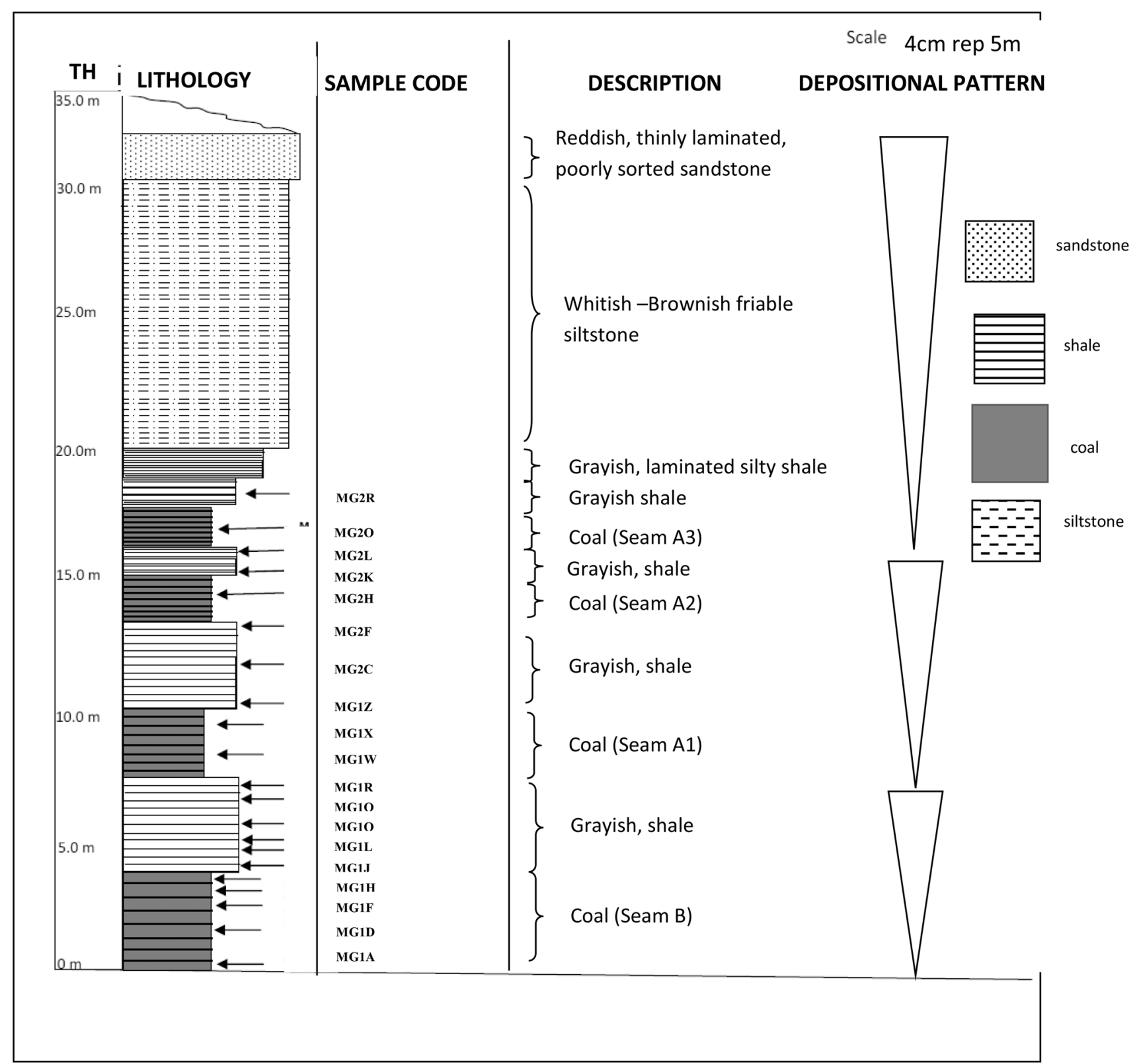

Fig. 4 Lithologic succession of Gombe Formation at the Maiganga mine (Phase I). The succession coarsens upward from coal, shale, siltstone to sandstone. The arrows indicate the selected and analysed samples. Note the coordinates: $10^{\circ} 02^{\prime} 39^{\prime \prime} \mathrm{N}, 11^{\circ} 12^{\prime} 17^{\prime \prime} \mathrm{E}$

with $n$-hexane as the mobile phase. The extracts were first deasphaltened by adding $n$-pentane to the extract. The $n$-pentane dissolves the maltene fractions (saturates, aromatics and NSO) and then agitated and centrifuged to make sure all the maltene is dissolved in the $n$-pentane and the asphaltenes precipitated. The saturated and aromatic hydrocarbon fraction were analysed by gas chromatography-mass spectroscopy by trace 1310 gas chromatograph with ISQ 


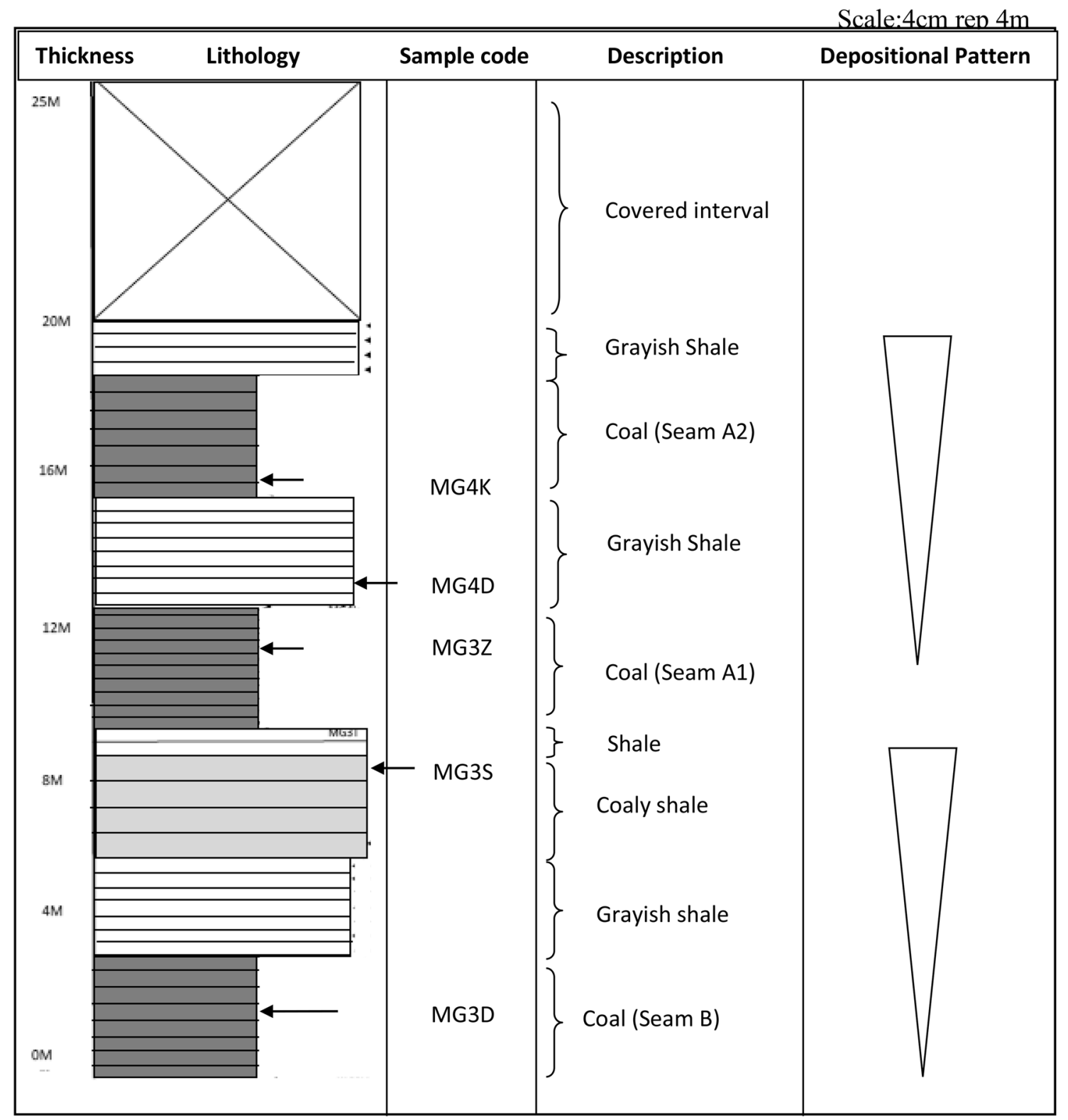

Fig. 5 Lithologic succession of Gombe Formation at Maiganga mine (Phase II). The succession coarsens upward from coal, shale, coaly shale. The arrows indicate the selected and analysed samples. Coordinates: $\left(10^{\circ} 04^{\prime} 46^{\prime \prime} \mathrm{N}, 11^{\circ} 12^{\prime} 23^{\prime \prime} \mathrm{E}\right)$

LT single-quadrupole mass spectrometer and Agilent 7890 B gas chromatograph with a 5977 A mass spectrometer detector. The saturate fraction was weighed into a $2 \mathrm{ml} \mathrm{sam-}$ ple vial, cholane and cyclohexane was added and injected into the GC-MS machine, while the same procedure was repeated for aromatic except that orthoterphenyl (OTP) was added to serve as internal standard for the GC-MS analysis.
The organic petrography of the samples was determined by reflected light microscopy on polished specimens made from crushed samples mounted in epoxy resin. The polished briquettes were prepared from crushed 1-mm size samples (coal and shale) and mounted in epoxy resin. Ordinary white reflected light from a tungsten lamp and violet-blue light from a high-pressure mercury lamp were used to initiate 


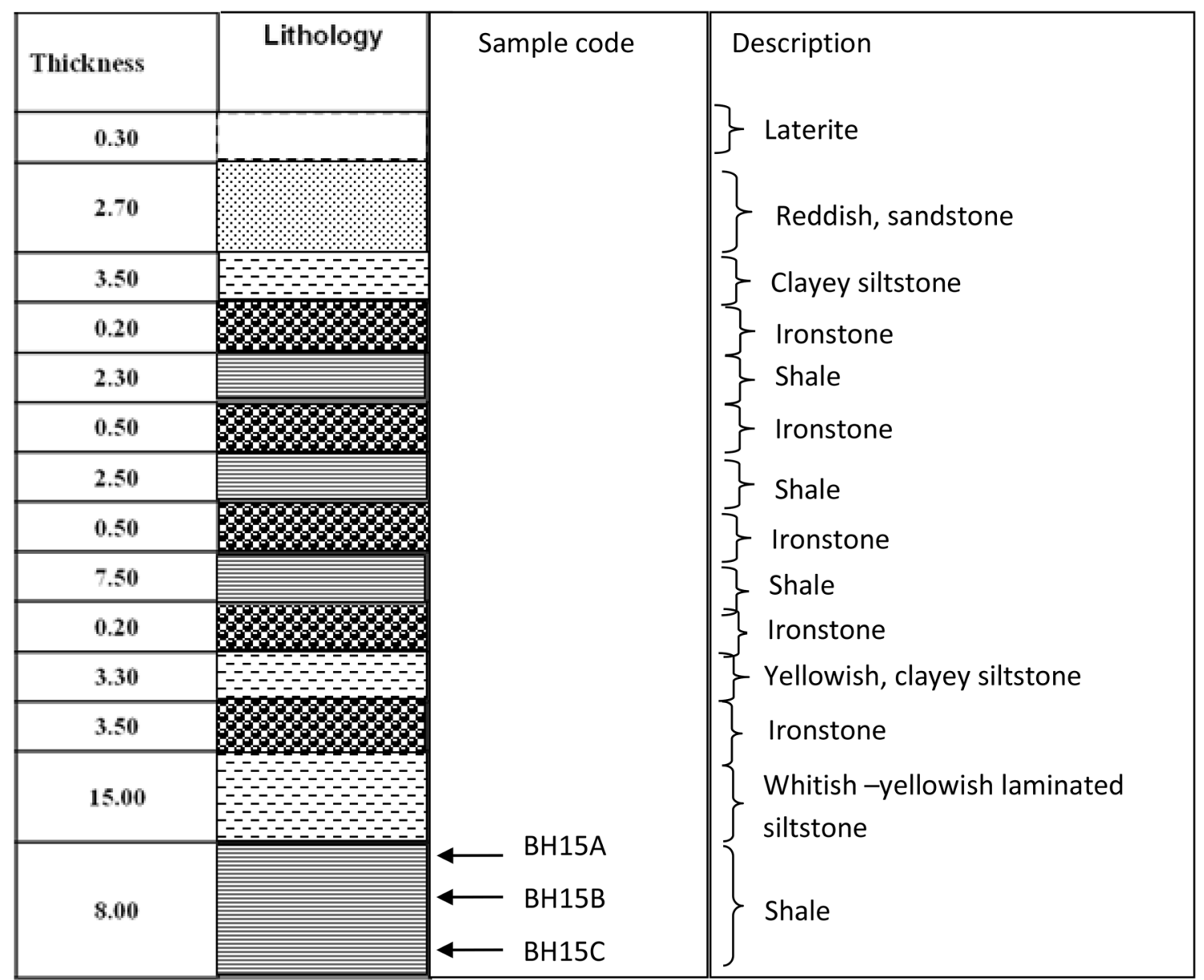

Fig. 6 Litholog of borehole sampled at Maiganga. GPS: $x=734,251, y=1,105,749, z=458$. The log shows shale, siltstone and ironstone intercalation. Arrow indicates selected samples

fluorescence. Maceral observation was carried out on a Leitz MPV-2 photomicroscope. The composition of maceral was determined by means of a swift automatic point counter; each composition was based on at least 500 counts.

\section{Results and discussion}

\section{Organic matter richness}

The organic carbon content of the coals ranges between 32.40 and 65.29 wt $\%$ with an average of $38.03 \mathrm{wt} \%$, shales from 0.64 to $4.84 \mathrm{wt} \%$ with an average of $3.14 \mathrm{wt} \%$, while coaly shales have an average of $12.1 \mathrm{wt} \%$ (Table 1). The minimum TOC value defining a good source rock is $0.5 \mathrm{wt} \%$ for shale, $0.3 \mathrm{wt} \%$ for carbonate and $1 \mathrm{wt} \%$ for clastic rock (Killops and Killops 1993). Generally, the range of $1.5-2 \mathrm{wt} \%$ has been generally accepted for good source rocks (Killops and Killops 1993; Hunt 1996a, b). However, the TOC values in the coal, shale and shaly coal samples exceeded the acceptable minimum values required for a potential source rock (Hunt 1996a, b) and thus indicate good source potential. This is corroborated by the average genetic potential (GP) value for the coals, shales and coaly shales which are $70.7 \mathrm{mg} / \mathrm{g}, 5.04 \mathrm{mg} / \mathrm{g}$ and $12.6 \mathrm{mg} / \mathrm{g}$, respectively. The genetic potential values are greater than $2 \mathrm{mg} / \mathrm{g}$ required for a potential source rock (Hunt 1996a, b; Peters et al. 2005) (Table 1). 


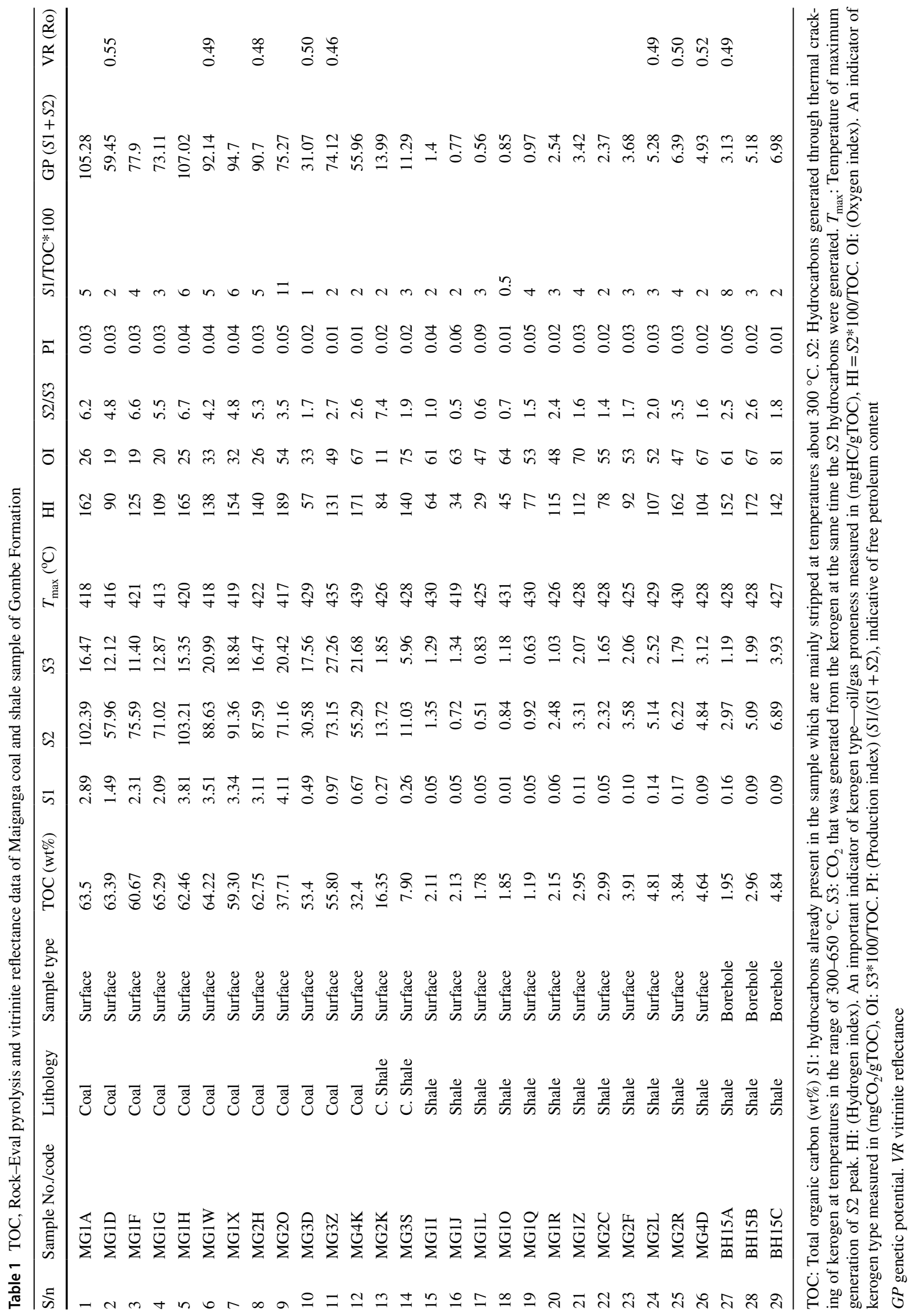


Fig. $7 S 2$ versus TOC plots for coal and shale samples of Maiganga coal mine, Gongola Basin. The plot indicates type III kerogen (gas prone) for the samples. The shale samples are organically lean. After Langford and Blanc-Valleron (1990)

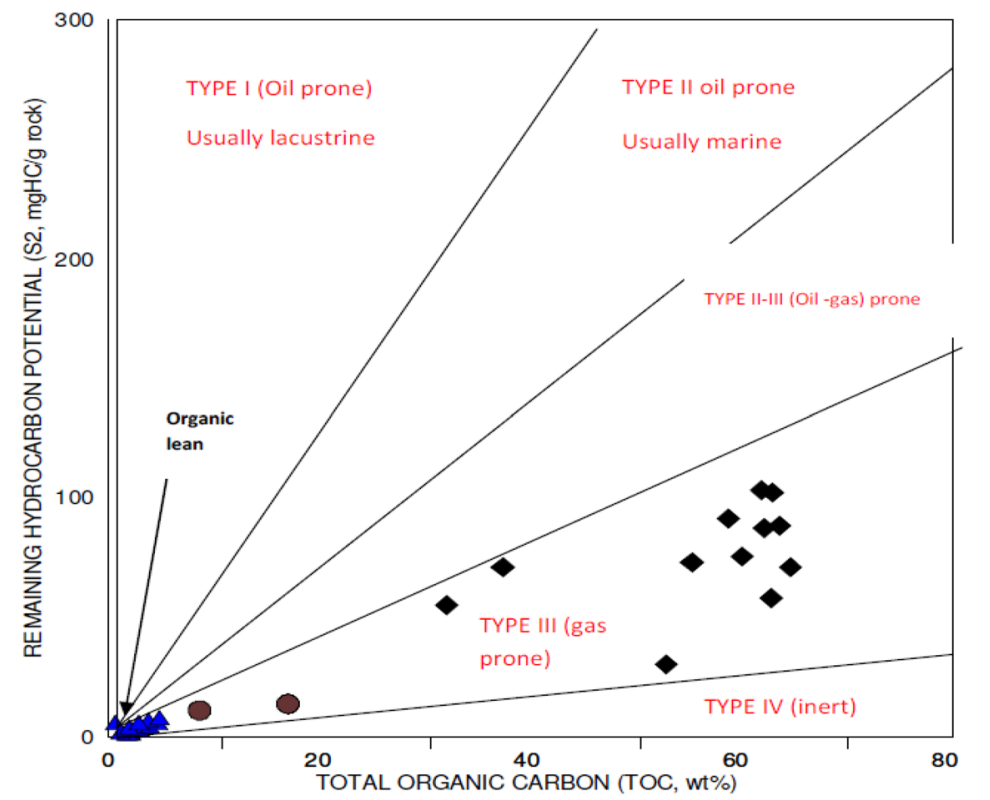

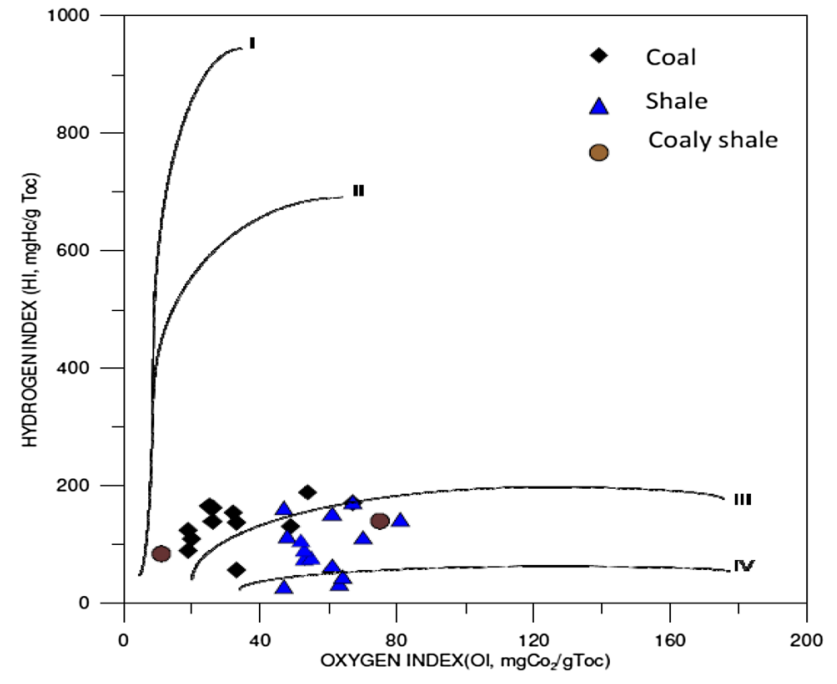

Fig. 8 Plot of HI versus OI for the classification of kerogen (1-1 V) of coal, coaly shale and shale samples from Maiganga mine, Gongola Basin. Most of the samples fall within type III kerogen (gas prone). After Van Krevelen (1961)

\section{Kerogen quality}

The quality of the organic matter contained in the samples was evaluated from their hydrogen index (HI). The hydrogen index for the coal ranges from 57 to $189 \mathrm{mg} / \mathrm{gTOC}$, shale between (29-172 mg/gTOC) and
(84-140 mg/gTOC) for coaly shale. HIs in all the samples are less than $200 \mathrm{mgHC} / \mathrm{gTOC}$ (Table 1) suggesting type III organic matter (Hunt 1996a, b). The plots of $S 2$ versus TOC (Fig. 7) indicated gas prone kerogen, i.e. type III organic matter. Plot of HI versus OI (Van Krevelen diagram) (Fig. 8) also confirms type III kerogen for the coal, shale and coaly shale samples. However, there are few samples of shale that fall under type IV kerogen. This is corroborated by plot of HI versus $T_{\max }$ (Fig. 9) and HI versus VR (Fig. 10) which indicates the organic matter is immature and mainly type III capable of generating mainly gas. Similarly, some shale samples fall under type IV kerogen which is inert. The $S 2 / S 3$ value ranges from (1.7-6.7), (1.9-7.4) to (0.5-3.5) for the coal, coaly shale and shale, respectively, indicating type III kerogen (Hunt 1996a, b).

\section{Hydrocarbon potential}

The $S 2$ yield ranges from 30.6 to $91.4 \mathrm{mg} / \mathrm{g}$ for the coals, $(2.97-6.89 \mathrm{mg} / \mathrm{g})$ for the shales and $(11.03-13.73 \mathrm{mg} / \mathrm{g})$ for the coaly shale (Table 1 ). The average values of the $S 2$ are $(68.7 \mathrm{mg} / \mathrm{g}),(4.92 \mathrm{mg} / \mathrm{g})$ and $(12.4 \mathrm{mg} / \mathrm{g})$, respectively. This is further corroborated by the genetic potential value greater than $2 \mathrm{mg} / \mathrm{g}$ for most of the samples (Table 1). These values indicate moderate-to-good source rock potential (Hunt 1996a, b), and it is comparable to what 
Fig. 9 Plot of hydrogen index (HI) against $T_{\max }$ of coal, coaly shale and shale samples from Maiganga mine, Gongola Basin. Most of the samples are immature and fall within type III kerogen (gas prone) typical of terrestrially sourced organic matter

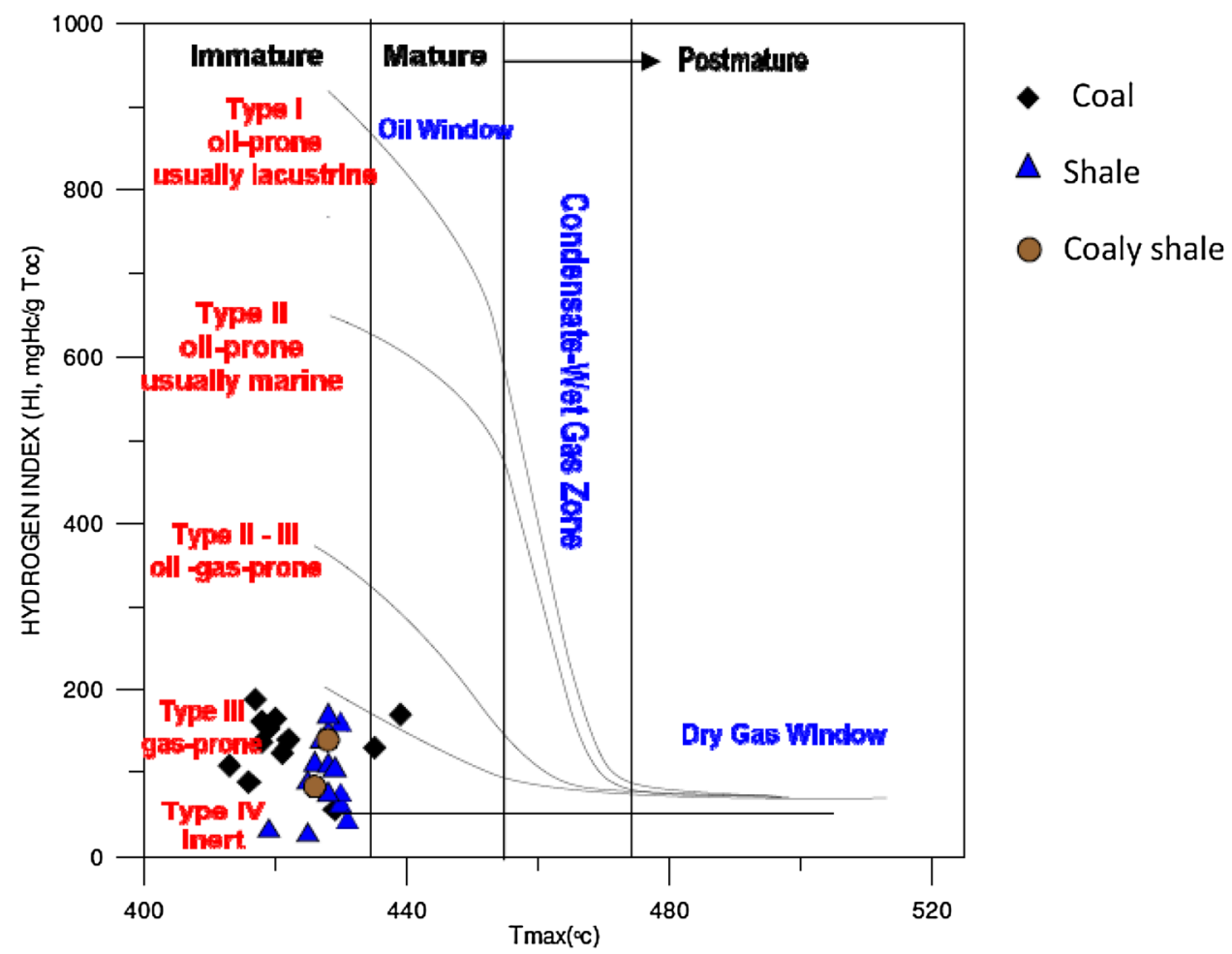

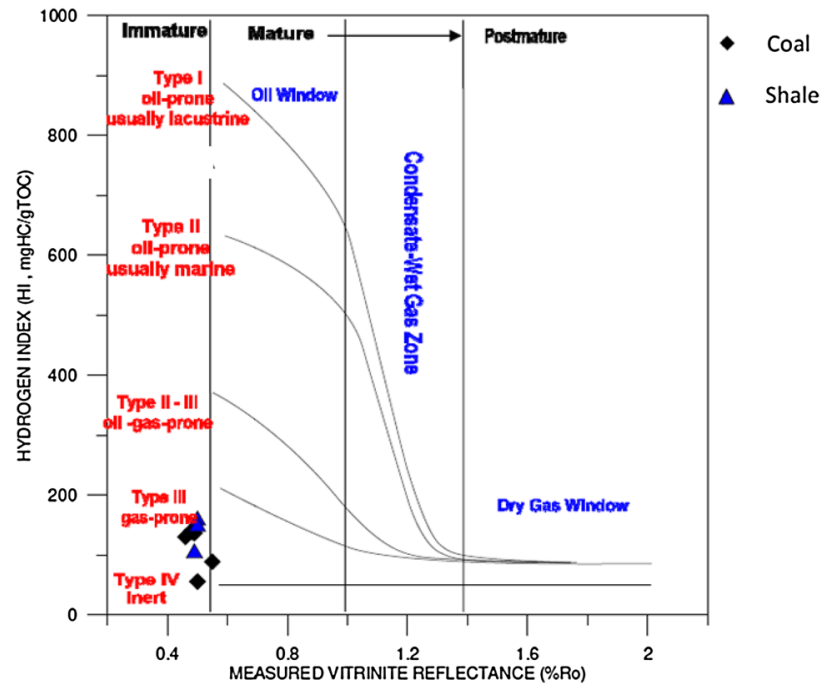

Fig. 10 Plot of hydrogen index (HI) against vitrinite reflectance of coal and shale samples from Maiganga mine, Gongola Basin. Most of the samples are immature and fall within type III kerogen (gas prone) typical of terrestrially sourced organic matter

was observed in other hydrocarbon generating coal basins in the world such as Cooper-Eromanga Basin in Australia and Taranaki basin in New Zealand. The results showed that all the samples have low production index (PI) (less than 0.1) indicating low level conversion (Figs. 11, 12).

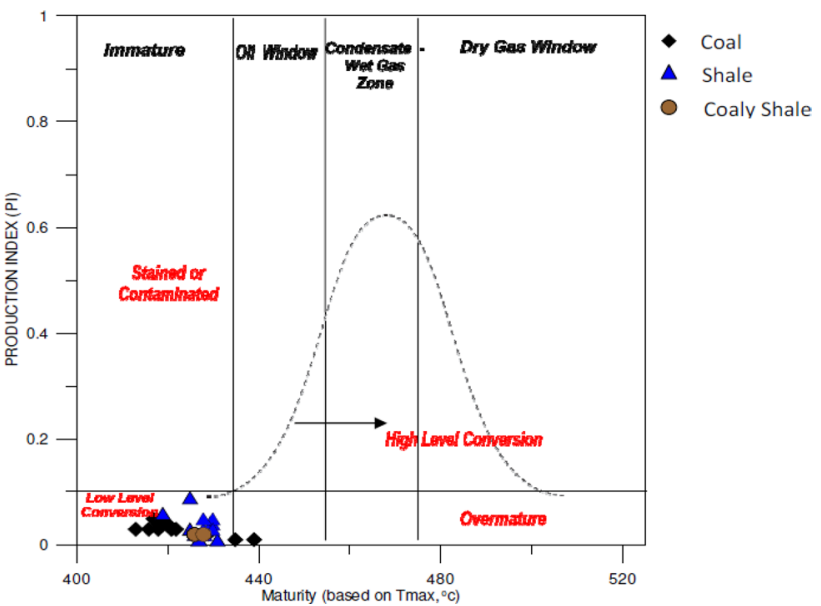

Fig. 11 Plot of production index (PI) against $T_{\max }$ of coal, coaly shale and shale samples from Maiganga mine, Gongola Basin. All the samples are immature and have low level conversion of kerogen to oil

\section{Source of the organic matter and palaeodepositional environments}

To infer the environments of deposition of the source rocks, saturate, aromatic biomarker ratios and parameters were used (Tables 2,3). The extract from the gas 


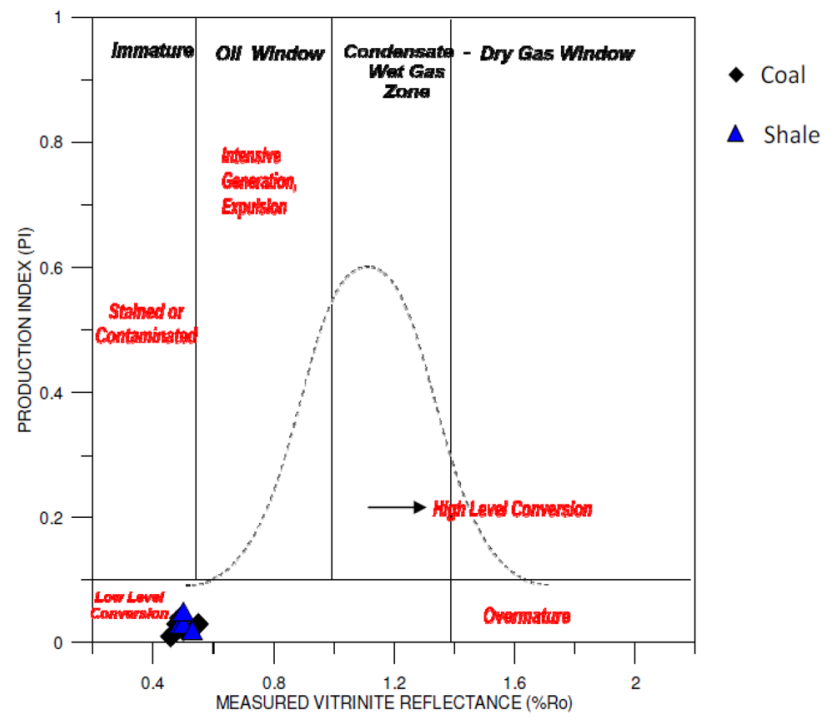

Fig. 12 Plot of production index (PI) against vitrinite reflectance of coal and shale samples from Maiganga, Gongola Basin. All the samples are immature and have low level conversion of kerogen to oil

chromatography was resolved into normal paraffin, isoprenoids. The samples were characterized by high molecular weight $n$-alkanes. The $n$-alkanes are the dominant component of the aliphatic hydrocarbon fraction and show variation in quantity and distribution in the samples analysed. The ion fragmentograms of the saturate fractions analysed by gas chromatography and mass spectrometry were recorded in $(\mathrm{m} / \mathrm{z} 191, \mathrm{~m} / \mathrm{z} 217, \mathrm{~m} / \mathrm{z} 218$ and $\mathrm{m} / \mathrm{z} 259$ ) corresponding to tricyclic and pentacyclic terpanes, steranes, diasteranes and tetracyclic polyprenoids, while the aromatic fractions were recorded on the $\mathrm{m} / \mathrm{z} 253, \mathrm{~m} / \mathrm{z} 251$ and $\mathrm{m} / \mathrm{z} 245$ corresponding to monoaromatic steroids, triaromatic steroids and triaromatic methyl steroids, respectively (Appendix). The $n$-alkanes distribution in the coal source rocks ranges from $\mathrm{C}_{10}-\mathrm{C}_{41}$ maximizing at $\mathrm{C}_{29}$ (Table 2) (Fig. 13a-d). This pattern indicates organic matter derived mainly from terrestrial organic matter. High proportions of long-chain $\mathrm{C}_{27}-\mathrm{C}_{35}$ members relative to the total $n$-alkanes especially are typical of terrestrial higher plants (Miranda et al. 1999). The shale source rocks range from $\mathrm{C}_{9}-\mathrm{C}_{41}$ also maximizes at $\mathrm{C}_{16}$ and $\mathrm{C}_{29}$ (Table 2) (Fig. 13e-g) indicating mixed sources.

The predominance of pristane $\left(n-\mathrm{C}_{17}\right)$ over phytane $\left(n-\mathrm{C}_{18}\right)$ supports humic origin of the organic matter for the coal source rocks deposited in a mixed/transitional environment and less reducing environmental condition (Peters et al. 2005). $\mathrm{Pr} / \mathrm{Ph}$ ratio (Table 2) for the coal source rocks ranges from 2.15 to 3.51 (average 2.79),

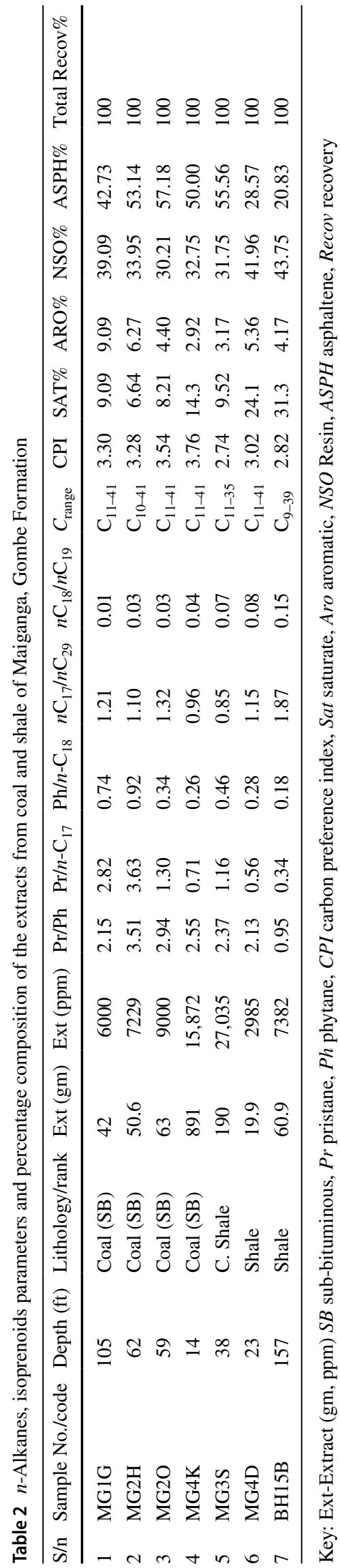

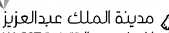

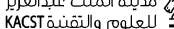




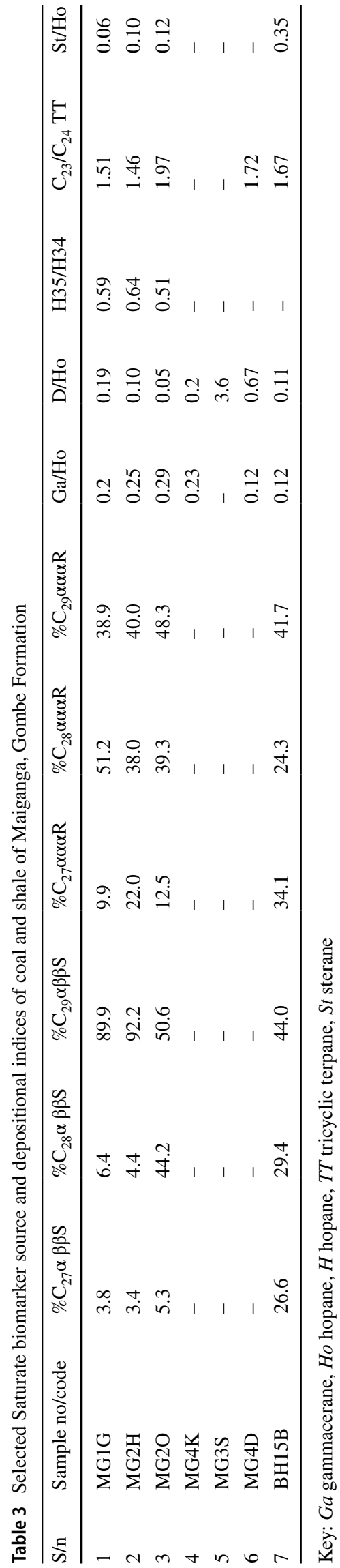

while the shale source rocks range between 0.95 and 2.37 (average 1.82) indicating coastal swamp and fluvio-deltaic depositional environment in sub-oxic to oxic setting (Peters et al. 2005).

The plot of $\mathrm{Pr} / n-\mathrm{C}_{17}$ versus $\mathrm{Ph} / n-\mathrm{C}_{18}$ (Fig. 14) also confirms terrestrial and mixed sources for the organofacies corroborated by the high values of $n \mathrm{C}_{17} / n \mathrm{C}_{29}$ over $n \mathrm{C}_{18} / n \mathrm{C}_{19}$. The coals are rich in $\mathrm{C}_{29} \alpha \beta \beta \mathrm{S}$ steranes (> 50\%) and $\mathrm{C}_{29} \alpha \alpha \alpha \mathrm{R}$ sterane ( 40\%). This is an indication of significant land plants contribution as evidenced from the very low $\mathrm{C}_{27}$ steranes (Table 3 ). The shale also has high $\mathrm{C}_{29}$ steranes but with appreciable quantity of $\mathrm{C}_{27}$ and $\mathrm{C}_{28} \alpha \beta \beta S$ sterane (26\% and 29\%) and (34\% and $24 \%$ ) in $\mathrm{C}_{27} \alpha \alpha \alpha \mathrm{R}$ and $\mathrm{C}_{28} \alpha \alpha \alpha \mathrm{R}$ sterane confirming possible marine contribution for the source (Table 3 ) and (Fig. 15). The appreciable quantity of $\mathrm{C}_{27}$ and $\mathrm{C}_{28}$ in the shale sample $\mathrm{BH} 15 \mathrm{~B}$ also reflects contributions from phytoplankton; algae, diatoms, dinoflagellates (Peters et al. 2005). This is in agreement with plot of $\mathrm{Pr} / n-\mathrm{C}_{17}$ versus $\mathrm{Ph} / n-\mathrm{C}_{18}$, though there is absence of $\mathrm{C}_{30}, 24$ $n$-propyl cholestane (biomarker of chrysophyte algae) to strengthen the marine algae contribution. However, the presences of $\mathrm{C}_{30}$ tetracyclic polyprenoids (TPP) a marker of lacustrine algae support fresh water lacustrine depositional conditions. The sterane/hopane ratio values range from 0.06 to 0.35 (Table 3 ). This ratio is $(<0.6)$ which suggest incorporation of high level of bacterial inputs commonly associated with terrigenous organic matter in coals (non-marine organic matter) (Norgate et al. 1999). The appreciable quantity of homohopanes $\left(\mathrm{C}_{31}-\mathrm{C}_{35}\right)$ in all the samples suggests that bacteriohopanetetrol and other polyfunctional $\mathrm{C}_{35}$ hopanoids (Wang et al. 1996) commonly found in prokaryotic micro-organisms were significant contributors to the biomass.

The predominance of $\mathrm{C}_{29}$ triaromatic steroid (TAS) indicates a terrestrial source contribution for the organic matter as evident from the ternary plot of $\mathrm{C}_{27}, \mathrm{C}_{28}, \mathrm{C}_{29}$ monoaromatic steroid (MAS) (Fig. 16). The cross plot of (9MP/(9MP + 1MP) versus Paq (Fig. 17) further confirms terrestrial land plants contribution for the organic matter of the coals and shales. The low amounts of dibenzothiophene to phenanthrene (DBT/PH) (Table 4) and cross plots of DBT/PH versus $\mathrm{Pr} / \mathrm{Ph}$ (Fig. 18) and sulphur versus DBT/PHEN (Fig. 19) indicate deposition of the organic matter predominantly in lacustrine and/ or fluvial/deltaic environments (Hughes et al. 1995). There is an appreciable amount of $\mathrm{C}_{27}, \mathrm{C}_{28} \mathrm{MAS}$ in the shale sample BH15B which may suggest mixed sources. The presence of 1,2,5- and 1,2,7-trimethylnaphthalene (TMN) in the coal samples indicates both angiosperm and gymnosperms material contribution to the organic matter that formed the coals (Killops and Killops 2005). 

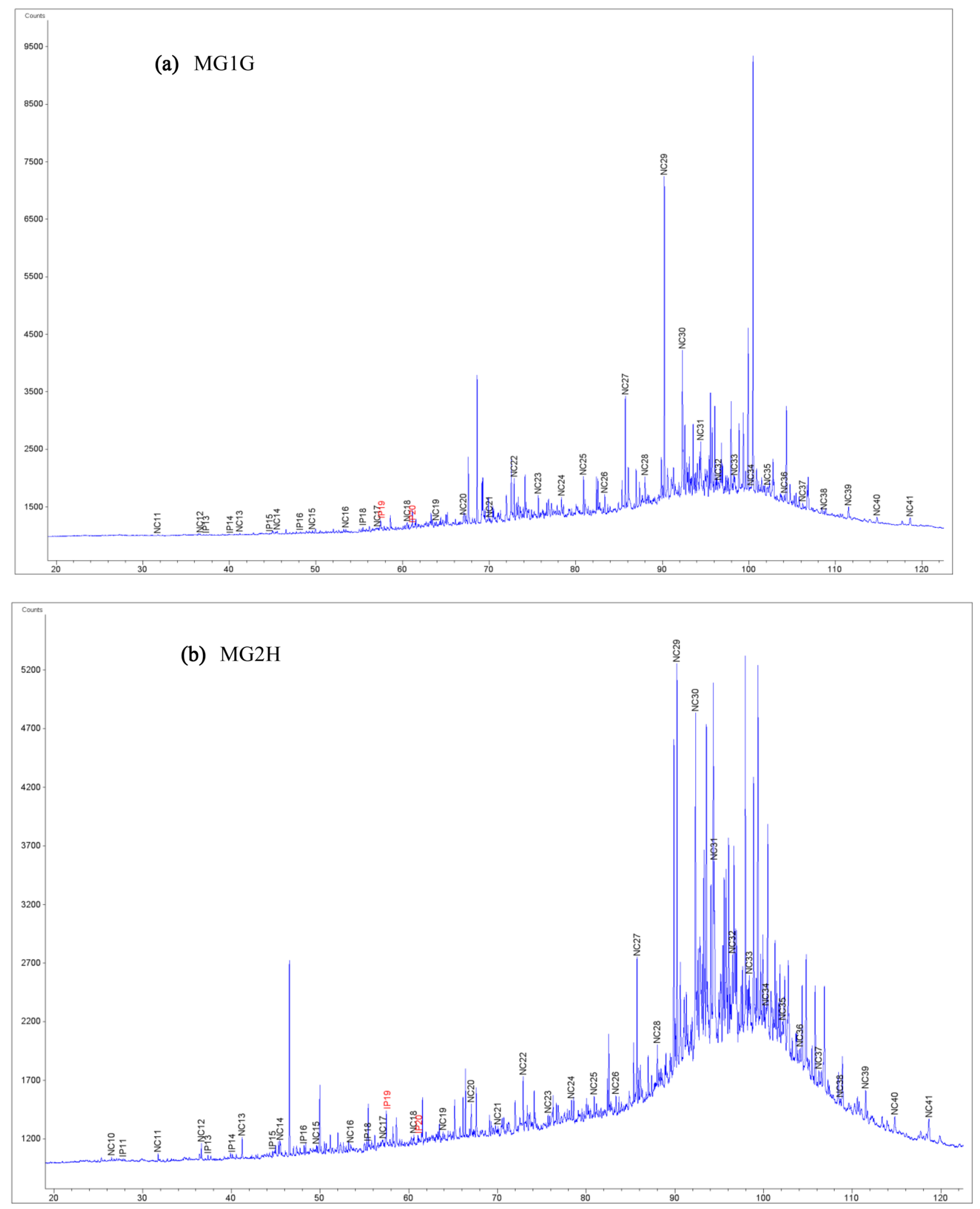

Fig. 13 Ion chromatograms of samples showing the distribution of $n$-alkanes. a MG1G, b MG2H, c MG2O, d MG4K, e MG3S, f MG4D, g BH15B 
340

Journal of Petroleum Exploration and Production Technology (2020) 10:327-350
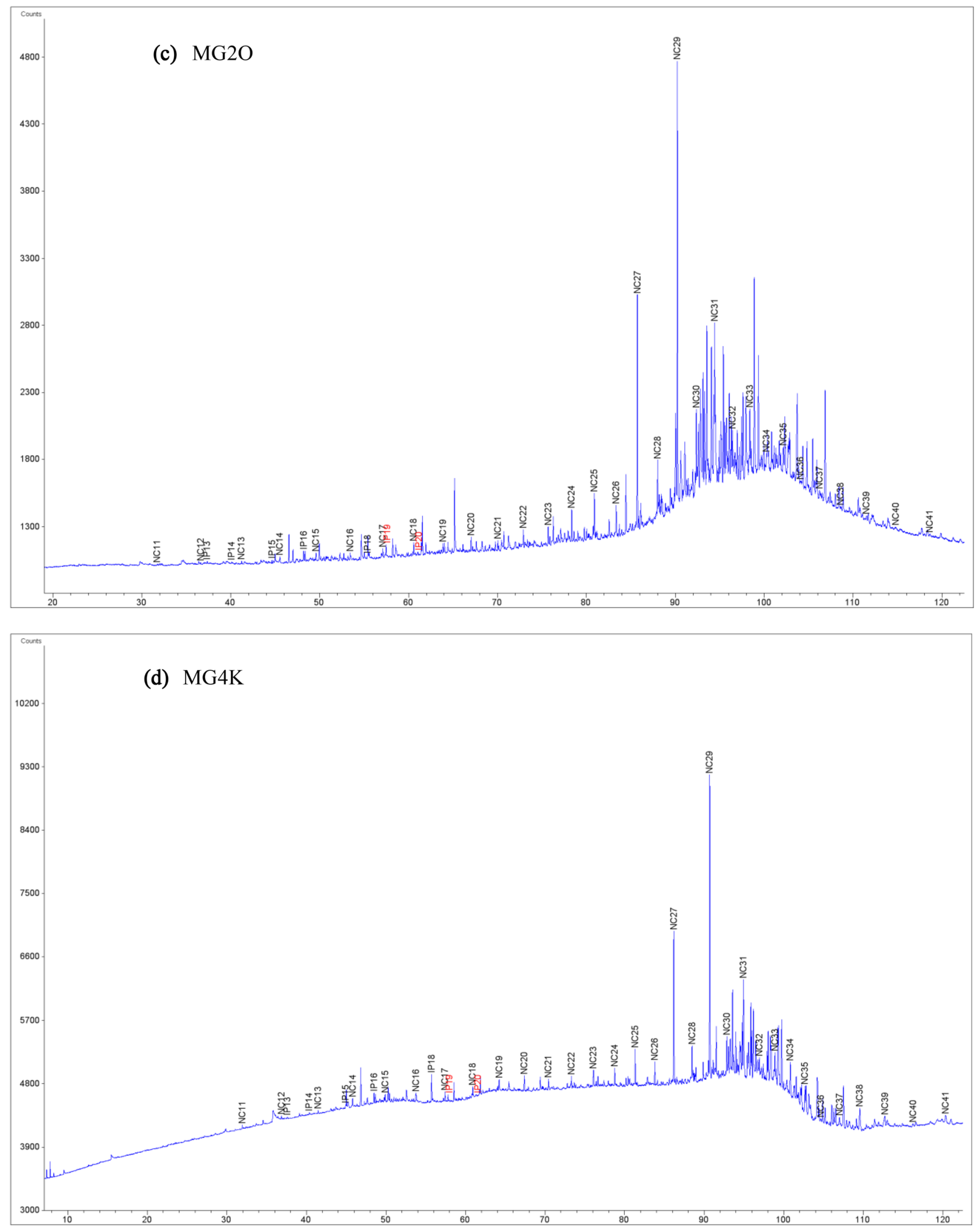

Fig. 13 (continued)

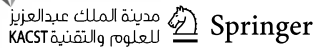



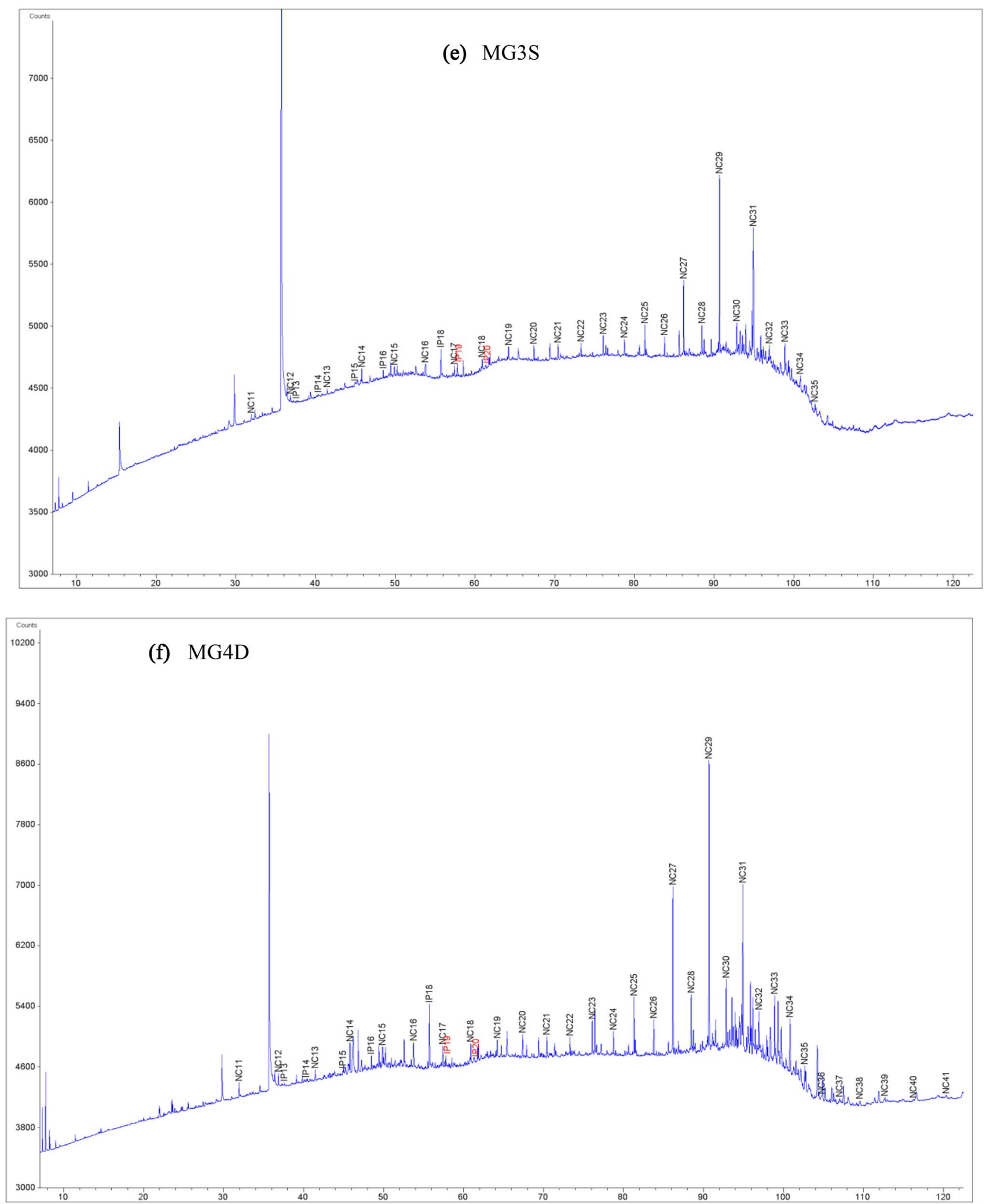

Fig. 13 (continued) 


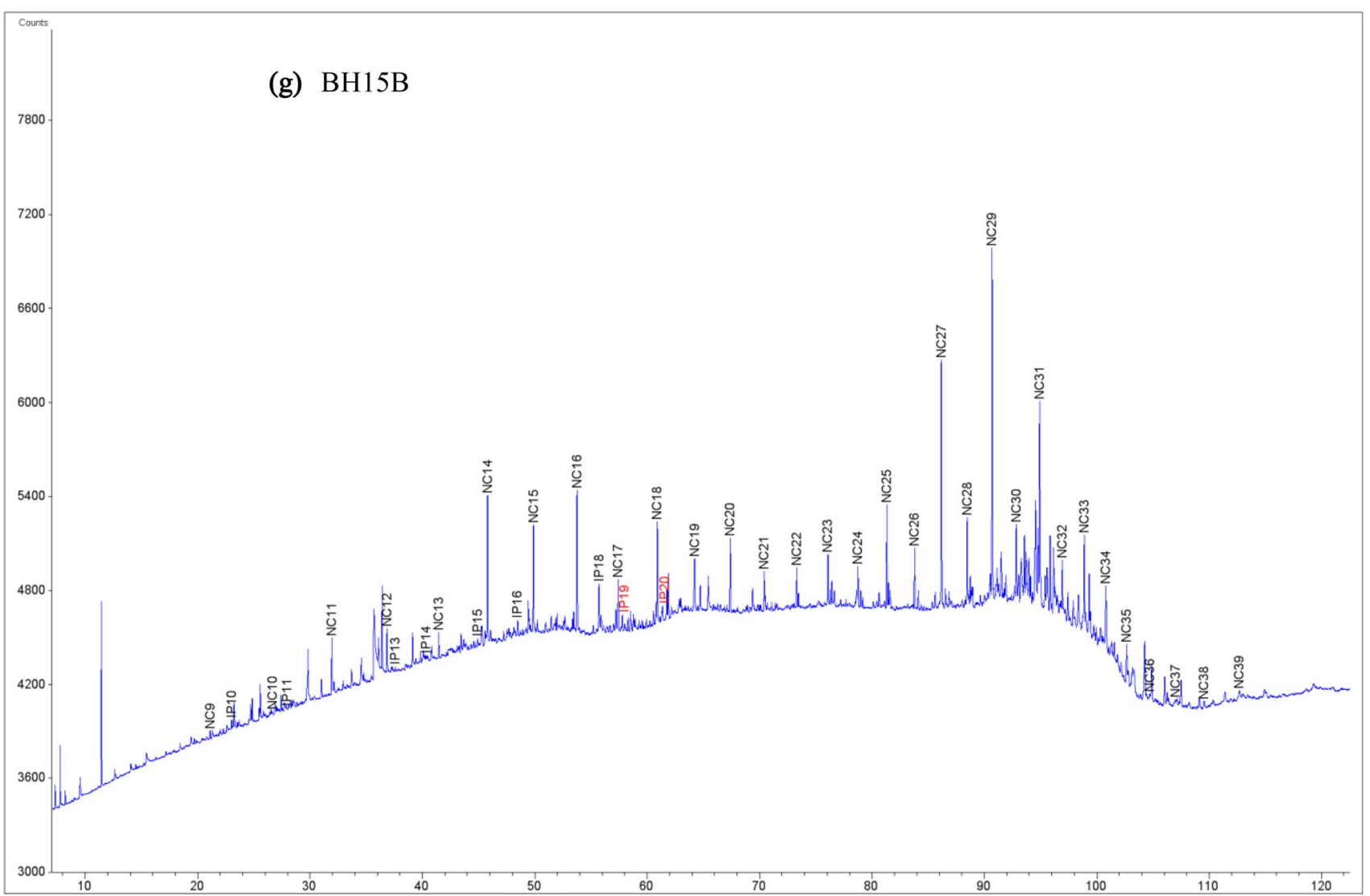

Fig. 13 (continued)

Fig. 14 Plot of $\mathrm{Pr} / n-\mathrm{C}_{17}$ versus $\mathrm{Ph} / n-\mathrm{C}_{18}$ of coal and shale samples of Maiganga, Gombe formation. The coals fall within the terrestrial sources in oxic depositional settings, shales plotted within the mixed sources. after Peters et al. (2005)

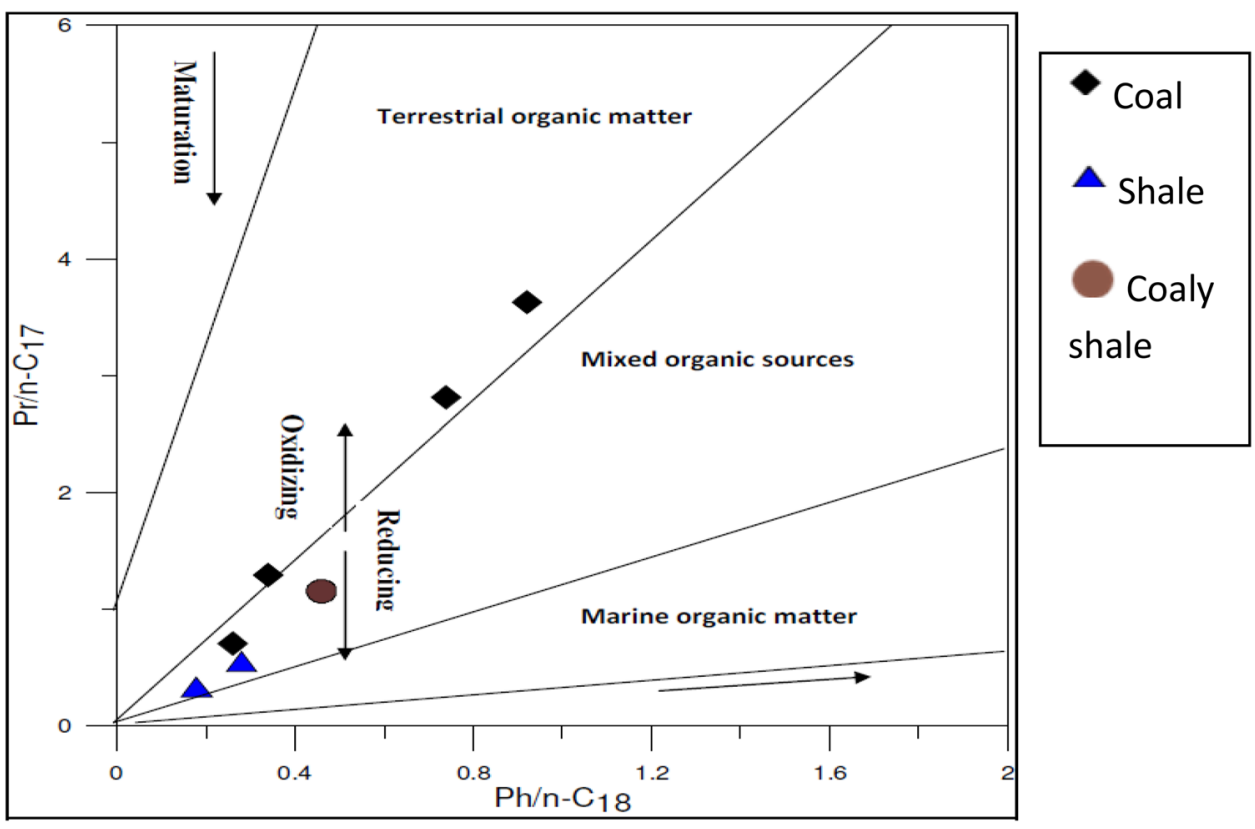




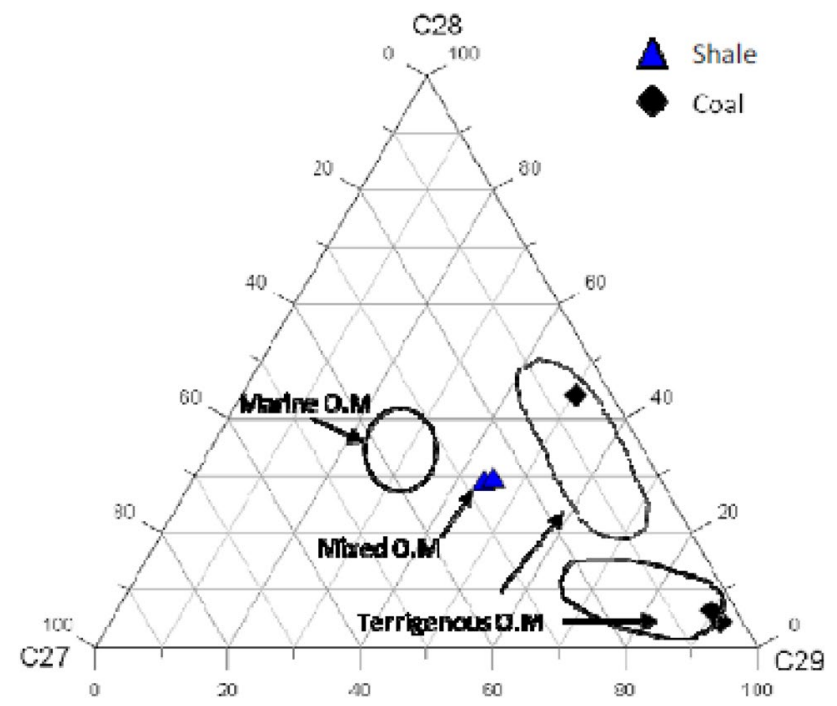

Fig. 15 Ternary diagram of the distribution of $\mathrm{C}_{27}, \mathrm{C}_{28}, \mathrm{C}_{29}$ steranes in Maiganga coal and shale, Gombe Formation. The coals are plotted in terrigenous portion due to predominance of $\mathrm{C}_{29}$. After Moldowan et al. (1985)

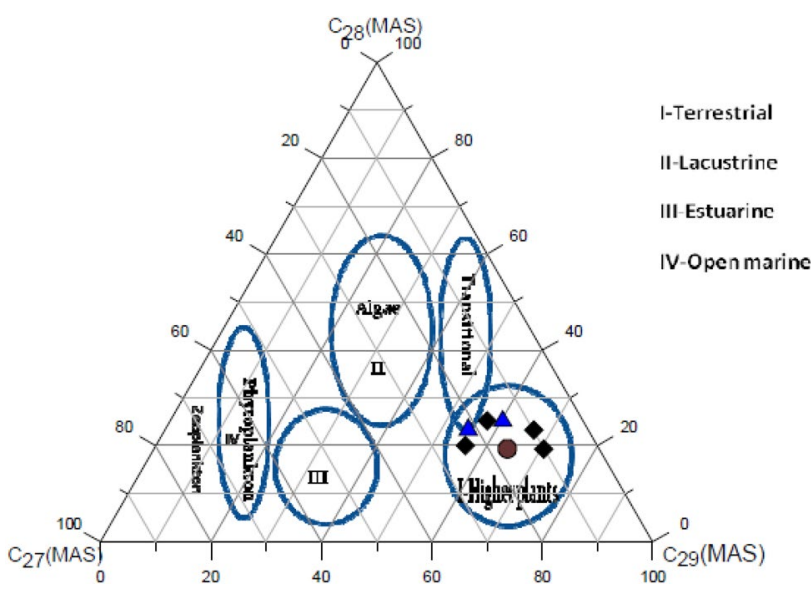

Fig. 16 Ternary diagram of the distribution of $\mathrm{C}_{27}, \mathrm{C}_{28}, \mathrm{C}_{29}$ monoaromatic steroid in Maiganga coal, shale and coaly shale, Gombe Formation. The coals are plotted in terrigenous portion due to predominance of $\mathrm{C}_{29}$ MAS. After Moldowan et al. (1985)

\section{Thermal maturity and hydrocarbon potential}

The thermal maturity of all the samples is represented by $T_{\max }$ range of $413-439{ }^{\circ} \mathrm{C}$. The $T_{\max }$ of the coals ranges between 427 and $430{ }^{\circ} \mathrm{C}$ with an average of $428{ }^{\circ} \mathrm{C}$, shales between 419 and $431{ }^{\circ} \mathrm{C}$ with average value of $427^{\circ} \mathrm{C}$, while the coaly shale is between 426 and $428^{\circ} \mathrm{C}$, averaging $427{ }^{\circ} \mathrm{C}$. Table 1 shows that majority of the samples have $T_{\max }$ less than $435^{\circ} \mathrm{C}$ with exception of two coal samples having $435^{\circ} \mathrm{C}$ and $439^{\circ} \mathrm{C}$. The spiked $T_{\max }$ of these two samples (MG3Z and MG4K) having the threshold values for maturity could probably arise from impurities or weathering of the samples or possibly human error as there are no conditions that could possibly increase the maturity at that stratigraphic interval. Consequently, Clayton and King (1987) and Lo and Cardott (1995)) have shown that weathering in outcropping source rocks has significant effect on the amount and quality of organic matter obtained by Rock-Eval pyrolysis. This is also noted in the OI values for the two samples $49 \mathrm{mg} \mathrm{CO} /$ gTOC in MG3Z and $67 \mathrm{mg} \mathrm{CO}_{2} /$ gTOC for MG4K indicating the highest level of weathering in the sample package. The low production index (PI) recorded for all the samples $(<0.1)$ also indicates that they are thermally immature.

The vitrinite reflectance of the coals ranges from 0.46 to 0.55 Ro averaging $0.5 \mathrm{Ro}$, and shales range between 0.49 and 0.53 Ro with an average of 0.51 Ro (Tables 1,5 ). These average values are less than $0.55 \mathrm{Ro}$ and thus confirm the samples have low level to marginal maturity and late diagenetic stage for oil generation (Killops and Killops 2005). The plot of HI versus $T_{\max }$ (Fig. 9), HI versus VR (Fig. 10), PI versus $T_{\max }$ (Fig. 11) and PI versus VR (Fig. 12) all indicated that the samples are immature. The carbon preference index (CPI) which measures the odd/ even predominance of the $n$-alkanes showed the samples to range from 2.74 to 3.76 (Table 2). These values are essentially greater than unity, qualifying them as immature (Peters and Moldowan 1993). The predominance of asphaltenes and NSO in the extracts (Fig. 20) also confirms that the bitumen originates from low maturity level of kerogen cracking (Clayton and Law 1993).

The moretane/hopane and $T_{s} / T_{s}+T_{m}$ ratios in the samples range from $0.42-0.68$ to $0.07-0.12$, respectively (Table 6). These values suggest low maturity status (Peters et al. 2005). According to (Seifert and Moldowan 1986), $\mathrm{C}_{31}$ - or $\mathrm{C}_{32}$-homohopanes can be used to calculate $22 S /(22 S+22 R)$ ratio which is also a maturity parameter and is always close to it thermal equilibrium value (TEV). In this study, considering the $\mathrm{C}_{32}$ homohopane ratios of the coals ranging from 0.28 to 0.53 and $\mathrm{C}_{32}$ homohopane thermal equilibrium value of 0.6 , the $\mathrm{C}_{32}$ homohopane ratios fall below the equilibrium range and thus indicate thermal maturity level has not been reached. Most of the saturate maturity parameters are lower compared to their corresponding thermal equilibrium value 
Fig. 17 Organic matter source discrimination of Maiganga samples (After Ficken et al. 2000). The source of the organic matter in the samples was probably from land plant source

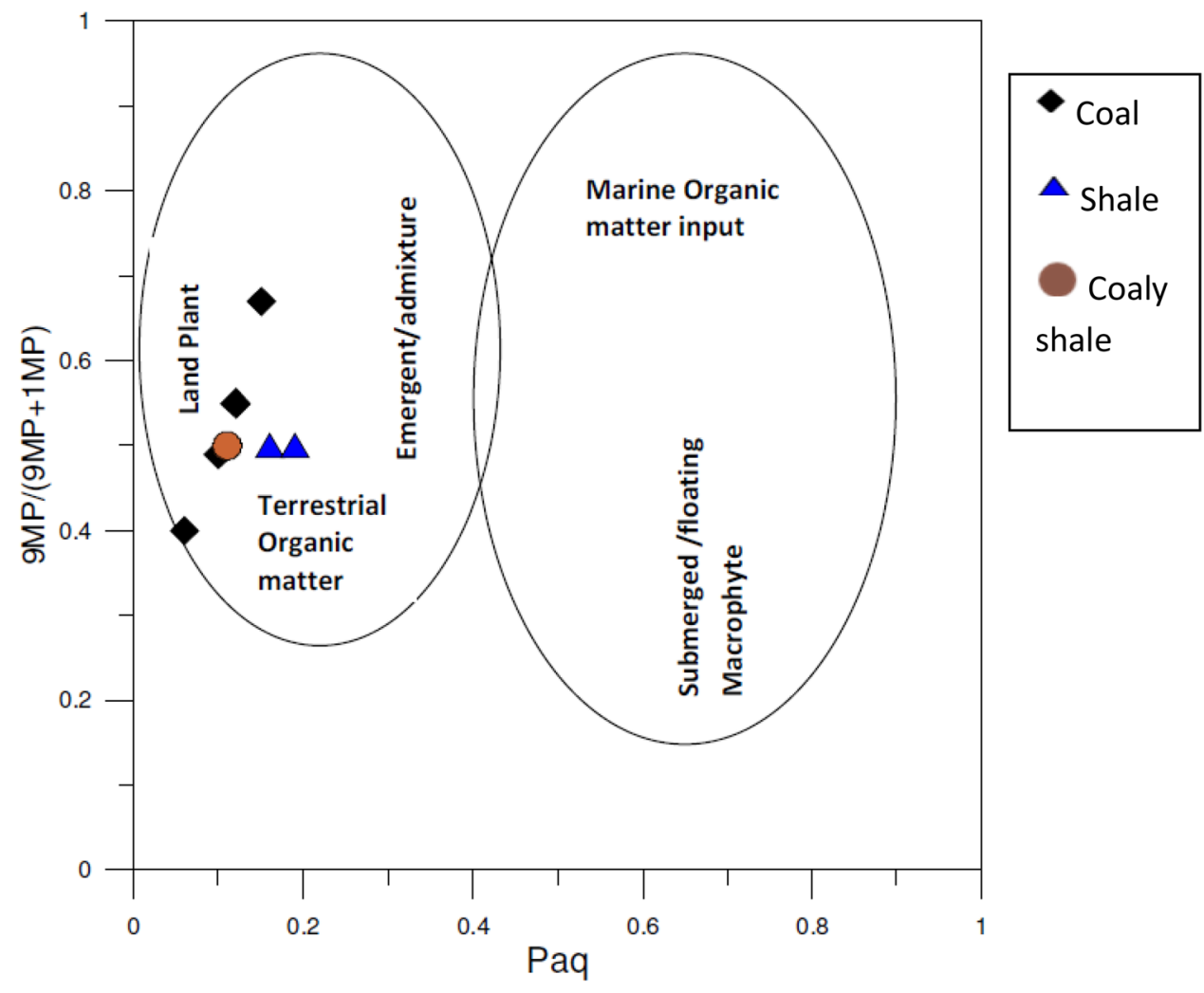

indicating low maturity status (Table 7) and hence have not reached onset of oil generation. The moretane/hopane and $T_{s} / T_{s}+T_{m}$ ratios in the samples range from $0.42-0.68$ to $0.07-0.12$, respectively, also indicate low maturity (Table 6).

The aromatic maturity indices were used to infer the maturity status of the organofacies. The calculated methyl phenanthrene index (MPI-1) and (MPI-2) are in close agreement with each other (Table 8 ). The MPI- 1 and MPI-2 of the coal range from $0.23-0.31$ to $0.31-0.50$, respectively, while the shaly source rocks range from $0.33-0.51$ to $0.45-0.56$, respectively. This suggests immature to marginally mature source rocks.

The proportion of vitrinite is the most abundant in the samples, and the vitrinite maceral in the coal ranges from 46.6 to $70 \%$, while the shale ranges from 35 to $45 \%$. The inertinite content ranges from 25 to $35 \%$ for the shale, while the coal ranges from 28.7 to $53 \%$ (Table 5). The high percentage of the vitrinite indicates gas prone and suggests they were deposited in close proximity to the source. The high percentages of the gas prone kerogenaceous debris and their low corresponding hydrogen index (HI) may be due to predepositional or post-depositional oxidation from the bulk of the sediments in the stratigraphic section or reworking of the organics.

According to (Hunt 1996a, b; Petersen and Nytoft 2006), the generation of petroleum from coal source rocks and its type are basically dependent on the hydrogen content. Many authors have suggested that liptinite content is essential in estimating the potential of the coal to generate liquid hydrocarbon. (Hunt 1991) has suggested 15-20\% liptinite, (Snowdon 1991) proposed $10 \%$ hydrogen rich maceral, while Mukophadhyay and Hatcher (1993) suggest 15-20\% liptinite content for a coal to generate oil. As indicated in (Table 5), the percentage oil prone for the shale is about $30-40 \%$ with respect to the liptinite content up to $40 \%$, whereas the coals have low liptinite of about (5\%) maximum, indicating that the tendency to generate liquid hydrocarbon is minimal. Peterson and Nytoft (2006) have proven that 

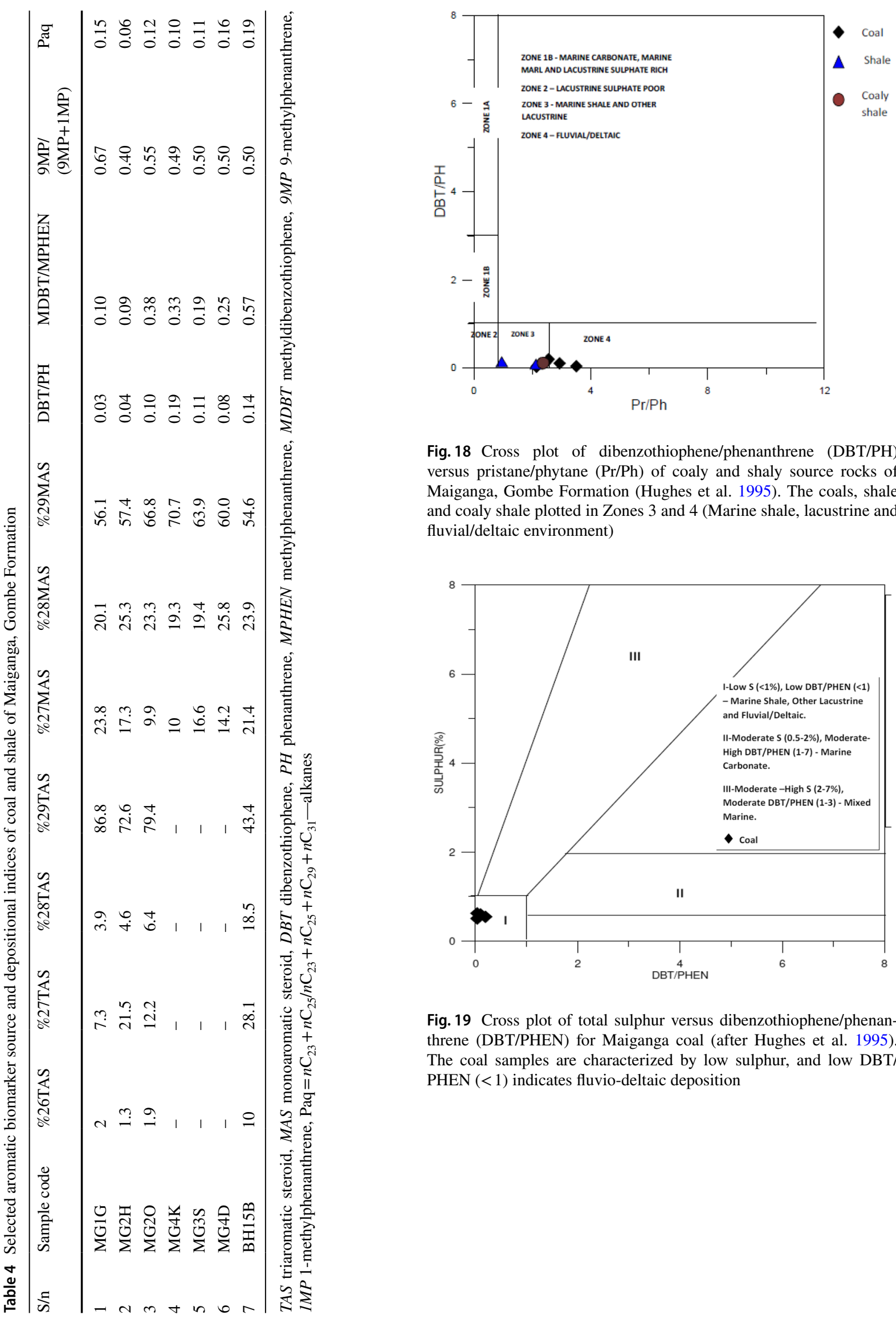

Fig. 18 Cross plot of dibenzothiophene/phenanthrene (DBT/PH) versus pristane/phytane $(\mathrm{Pr} / \mathrm{Ph})$ of coaly and shaly source rocks of Maiganga, Gombe Formation (Hughes et al. 1995). The coals, shale and coaly shale plotted in Zones 3 and 4 (Marine shale, lacustrine and fluvial/deltaic environment)

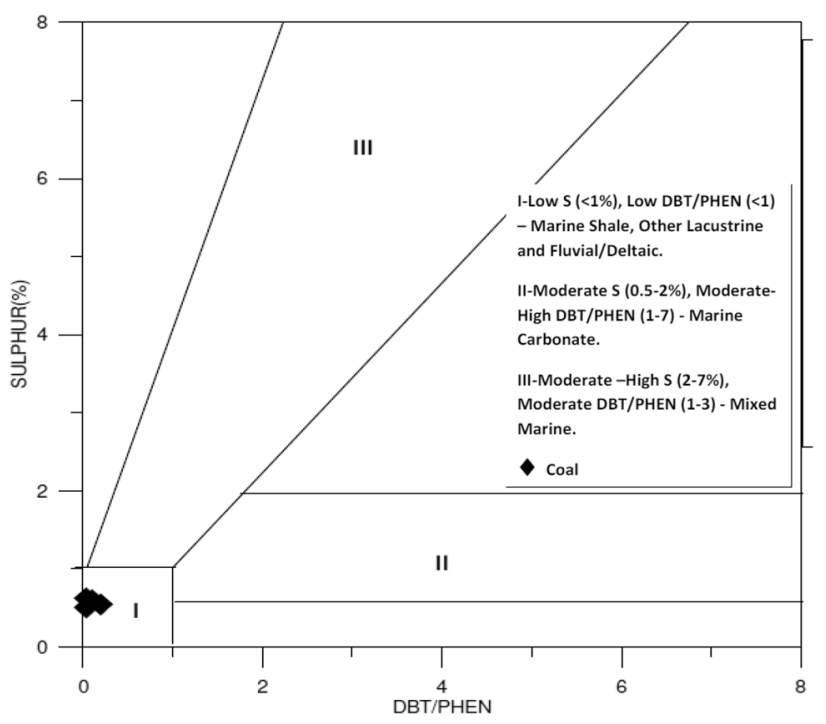

Fig. 19 Cross plot of total sulphur versus dibenzothiophene/phenanthrene (DBT/PHEN) for Maiganga coal (after Hughes et al. 1995). The coal samples are characterized by low sulphur, and low DBT/ PHEN $(<1)$ indicates fluvio-deltaic deposition 
Table 5 Maceral and vitrinite reflectance of coal and shale samples of Maiganga Gombe Formation

\begin{tabular}{lllllll}
\hline S/n & Sample code & Lithology & Liptinite (\%) & Vitrinite (\%) & Inertinite (\%) & VR \\
\hline 1. & MG1D & Coal & 0.4 & 46.6 & 53 & 0.55 \\
2. & MG1W & Coal & 1.9 & 59 & 39.1 & 0.49 \\
3. & MG2H & Coal & 1.3 & 70 & 28.7 & 0.48 \\
4. & MG3D & Coal & 5 & 50 & 45 & 0.50 \\
5. & MG3Z & Coal & 5 & 55 & 40 & 0.46 \\
6. & MG2L & Shale & 40 & 35 & 25 & 0.49 \\
7. & MG2R & Shale & 30 & 35 & 35 & 0.50 \\
8. & MG4D & Shale & 30 & 45 & 25 & 0.53 \\
9. & BH15A & Shale & 40 & 35 & 25 & 0.50 \\
\hline
\end{tabular}

$V R$ vitrinite reflectance

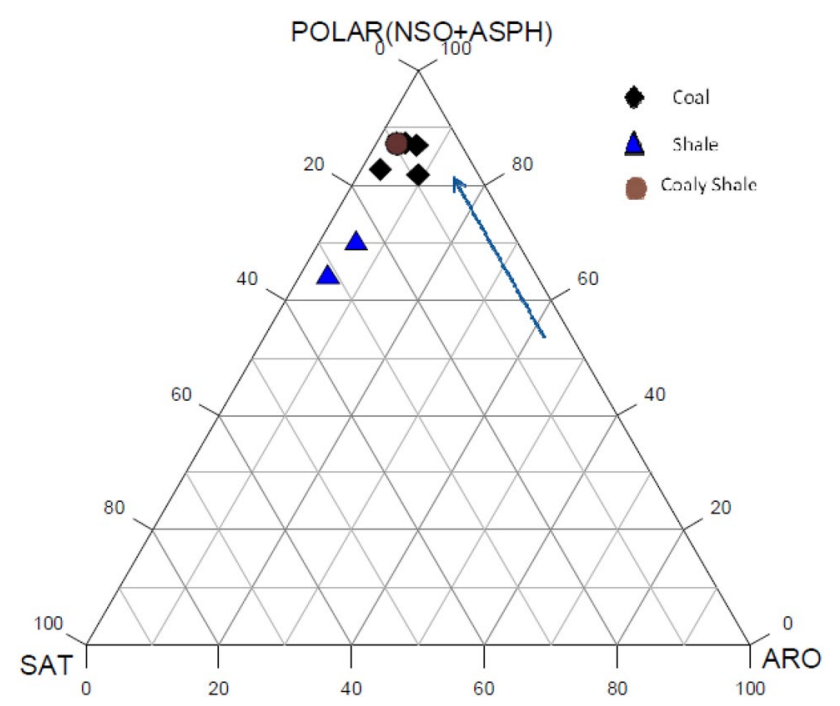

Fig. 20 Ternary diagram showing the proportion of saturated hydrocarbons, aromatic hydrocarbons and polar fraction (NSO + asphaltenes) in extracts of coal, shale and coaly shale source rocks of Maiganga, Gombe Formation. The samples have higher percentage of heterocompounds indicated by the arrow. After Clayton and Law (1993)
Table 7 Saturate biomarker ratio, thermal equilibrium value (TEV) and vitrinite reflectance of the samples

\begin{tabular}{llrlll}
\hline S/n & Saturate biomarker & \multicolumn{1}{l}{ Range } & TEV & VR (\%) & Maturity \\
\hline 1 & $S /(S+R)\left(\mathrm{C}_{29} \alpha \alpha \alpha\right)$ & $0.1-0.28$ & 0.55 & 0.80 & IM-LM \\
2 & $\left(\mathrm{C}_{29}\right) \beta \beta S /(\beta \beta S+\alpha \alpha \mathrm{R})$ & $0.04-0.61$ & 0.70 & 0.90 & IM-LM \\
3 & $\begin{array}{c}\text { Diasterane/C } \\
\text { sterane }\end{array}$ & $0.17-1.01$ & 1.00 & 1.40 & IM-LM \\
& Moretane/hopane & $0.42-0.68$ & 0.05 & 0.70 & IM-LM \\
4 & M & $0.07-0.12$ & 1.00 & 1.40 & IM \\
5 & $T_{s} /\left(T_{s}+T_{m}\right)$ & $0.28-0.53$ & 0.60 & 0.60 & IM-LM \\
\hline & $\mathrm{C}_{32}$ Homohopane & & & &
\end{tabular}

$T E V$ thermal equilibrium value, $I M$ immature, $L M$ low maturity, $V R$ vitrinite reflectance

Table 6 Selected saturate biomarker maturity indices of coal and shale sample of Maiganga, Gombe Formation

\begin{tabular}{llrlllllll}
\hline S/n & Sample no/code & Depth (ft) & Lithology/Rank & $\begin{array}{l}S /(S+\mathrm{R}) \\
\left(\mathrm{C}_{29} \alpha \alpha \alpha\right)\end{array}$ & $\begin{array}{l}\left.\mathrm{C}_{29}\right) \beta \beta \mathrm{S} / \\
(\beta \beta \mathrm{S}+\alpha \alpha \mathrm{R})\end{array}$ & $T_{s} / T_{s}+T_{m}$ & Mor/Hop & $\mathrm{H} 32 S /(R+S)$ & $\mathrm{TT} / \mathrm{Hop}$ \\
\hline 1 & MG1G & 105 & Coal(SB) & 0.28 & 0.26 & 0.12 & 0.54 & 0.53 & 0.04 \\
2 & MG2H & 62 & Coal(SB) & 0.28 & 0.61 & 0.08 & 0.62 & 0.40 \\
3 & MG2O & 59 & Coal(SB) & 0.12 & 0.37 & 0.07 & 0.61 & 0.28 & 0.03 \\
4 & MG4K & 14 & Coal(SB) & - & - & - & 0.63 & - & - \\
5 & MG3S & 38 & C. Shale & - & - & - & 0.55 & - & - \\
6 & MG4D & 23 & Shale & - & - & - & 0.68 & - & 0.09 \\
7 & BH15B & 157 & Shale & 0.1 & 0.04 & - & 0.42 & - \\
\hline
\end{tabular}

$T / T_{s}+T_{m}=$ Trisnorhopane, Mor/Hop = moretane/hopane, TT/Hop = tricyclic terpane/hopane, H32S/(R+S)=homohopanes, $S /(S+R)(\mathrm{C} 29 \alpha \alpha \alpha)$, $\mathrm{C} 29) \beta \beta \mathrm{S} /(\beta \beta \mathrm{S}+\alpha \alpha \mathrm{R}), \mathrm{SB}$ (sub-bituminous) 
Table 8 Selected Aromatic biomarker maturity indices of coal and shale sample of Maiganga, Gombe Formation

\begin{tabular}{llllllllllllll}
\hline S/n & Sample No./code & Depth (ft) & Lithology/rank & $\begin{array}{l}\text { TAS/ } \\
\text { (TAS+MAS) }\end{array}$ & MPI-1 & MPI-2 & DNR-1 & DNR-2 & MDR & MDR-1 & TDE-1 & TDE-2 & Rc \\
\hline 1 & MG1G & 105 & Coal (SB) & 0.27 & 0.31 & 0.50 & 2.70 & 1.31 & 0.66 & 1.15 & 5.10 & 0.27 & 0.56 \\
2 & MG2H & 62 & Coal (SB) & 0.39 & 0.23 & 0.32 & 4.12 & 1.09 & 0.77 & 0.90 & 7.55 & 0.19 & 0.51 \\
3 & MG2O & 59 & Coal (SB) & 0.19 & 0.23 & 0.31 & 4.11 & 1.88 & 0.42 & 1.64 & 9.44 & 0.40 & 0.51 \\
4 & MG4K & 14 & Coal (SB) & - & 0.34 & 0.45 & 4.51 & 1.81 & 0.38 & 2.64 & 5.43 & 0.37 & 0.58 \\
5 & MG3S & 38 & C. Shale & - & 0.37 & 0.50 & 2.99 & 1.55 & 0.67 & 1.12 & 8.21 & 0.26 & 0.59 \\
6 & MG4D & 23 & Shale & - & 0.33 & 0.45 & 2.88 & 1.18 & 0.39 & 2.01 & 8.42 & 0.30 & 0.57 \\
7 & BH15B & 157 & Shale & 0.20 & 0.51 & 0.56 & 3.40 & 1.94 & 0.81 & 0.83 & 4.79 & 0.38 & 0.68 \\
\hline
\end{tabular}

Methyl phenanthrene index $=($ MPI-1) and $($ MPI-2), Mono $=($ MAS $)$ and triaromatic steroids $($ TAS $)$, DNR $=$ dimethylnaphthalene ratio, $\mathrm{MDR}=$ methyldibenzothiophene ratio, $\mathrm{Rc}=$ calculated vitrinite reflectance of the aromatic biomarker, $\mathrm{MPI}-1=1.5(2 \mathrm{MP}+3 \mathrm{MP}) /$ $(\mathrm{P}+1 \mathrm{MP}+9 \mathrm{MP}) \quad \mathrm{MPI}-2=3(2 \mathrm{MP}) /(\mathrm{P}+1 \mathrm{MP}+9 \mathrm{MP}), \quad \mathrm{MDR}=4 \mathrm{MDBT} / 1 \mathrm{MDBT}, \quad \mathrm{MDR}-1=1 \mathrm{MDBT} / \mathrm{DBT}, \mathrm{DNR} 1=(2,6+2,7) /(1,5) \quad \mathrm{DMN}$, $\mathrm{Rc}=0.6(\mathrm{MPI}-1)+0.37$

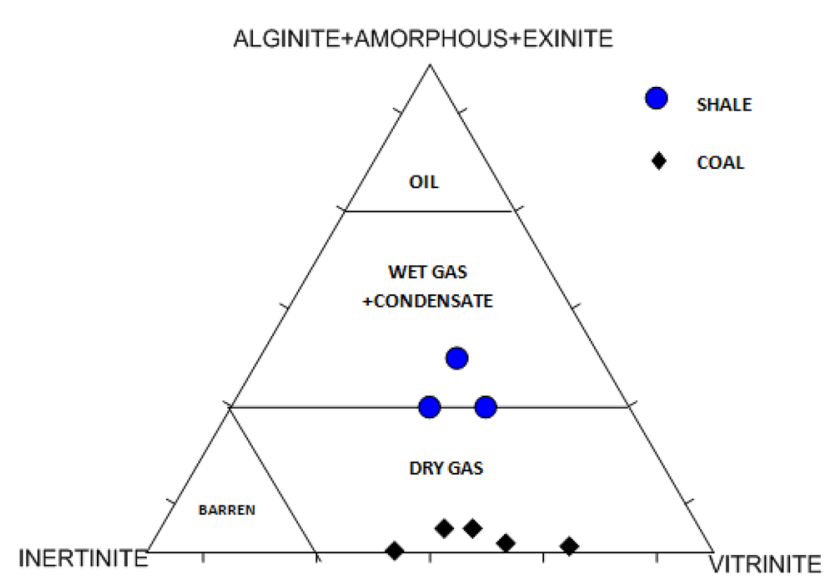

Fig. 21 Ternary plot indicating the proportion of the vitrinite, inertinite and liptinite and the corresponding hydrocarbon compared with the reference diagram of Tissot and Welte (1984). Plot indicates that the coal and shales are gas prone humic coals dominated by huminite could generate oil, though liptinite macerals and are more oil prone than huminite because of its high paraffinicity in structure and its ability to generate long-chain aliphatic component $\left(>\mathrm{C}_{20}-\mathrm{C}_{25}\right.$ ) (Isaksen et al. 1998).

The ternary plot of vitrinite, liptinite and inertinite revealed the type of hydrocarbon the source beds can generate (Fig. 21). Since vitrinite is the most abundant maceral in the coal samples analysed, it is logical to say that the coal has the potential to generate gaseous hydrocarbon (dry gas), while the shale has potential to generate wet gas (Fig. 21). All the samples are characterized by the absence of alginite and amorphous kerogen eliminating the presence of Type I kerogen typical of algae. The shales and coals are said to be dominated by Type III kerogen. The photomicrograph of the coal macerals is shown in Fig. 22. 

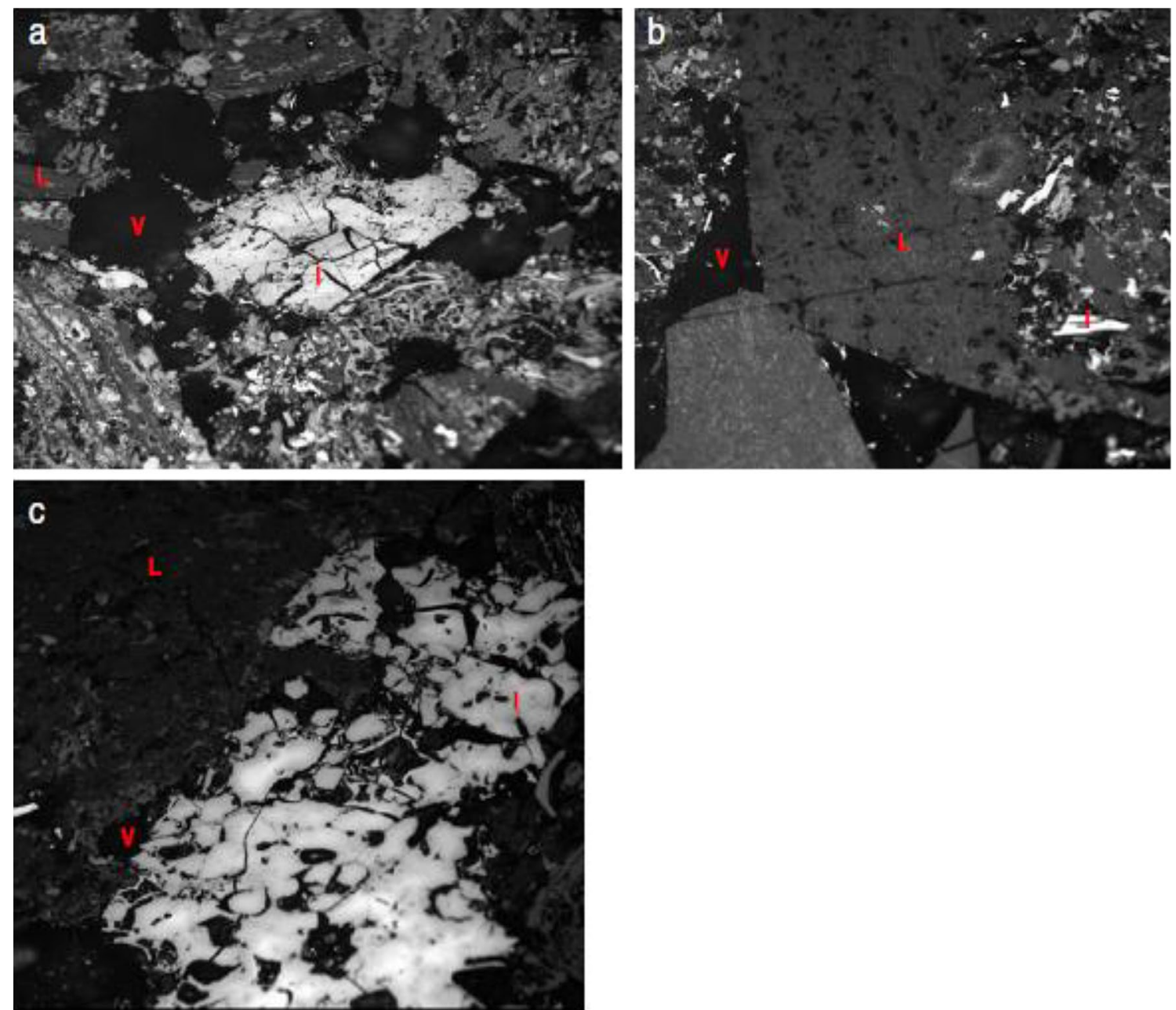

Fig. 22 Photomicrograph of coal sample a MG1D, b MG1W and $\mathbf{c}$ MG2H. (Liptinite shows grayish colouration, vitrinite is dark coloured, and inertinite is white under reflected light. V: vitrinite, I: inertinite, L: liptinite

\section{Conclusion}

In Conclusion, the Maastrichtian coal and shale of Gombe Formation, Gongola Basin show moderate-to-good source potential. The organic matter in the source rocks is mainly Type III from terrestrial land plant contribution though few samples fall under Type IV. The source rocks (coal and shale) have the potential to generate mainly gas and may probably generate oil if higher thermal maturity level is attained. Also, the coal facies were formed from organic matter derived from mainly terrestrial/terrigenous organic matter under oxidizing condition and deposited in the fluvial/deltaic environments, while the shaly facies were from mixed sources deposited under reducing environments.

Open Access This article is distributed under the terms of the Creative Commons Attribution 4.0 International License (http://creativeco mmons.org/licenses/by/4.0/), which permits unrestricted use, distribution, and reproduction in any medium, provided you give appropriate credit to the original author(s) and the source, provide a link to the Creative Commons license, and indicate if changes were made. 


\section{Appendix}

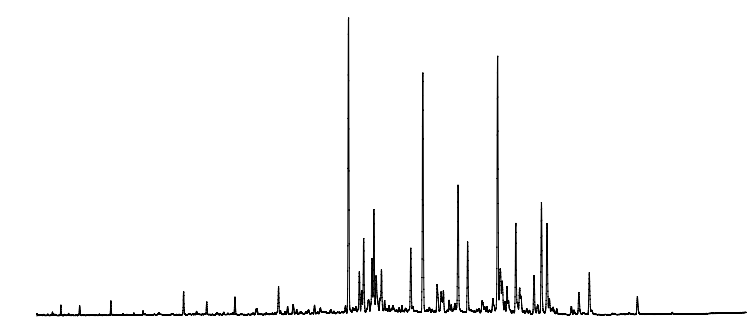

$m / z$ 191: Tri- and Pentacyclics Terpanes for sample BH15B

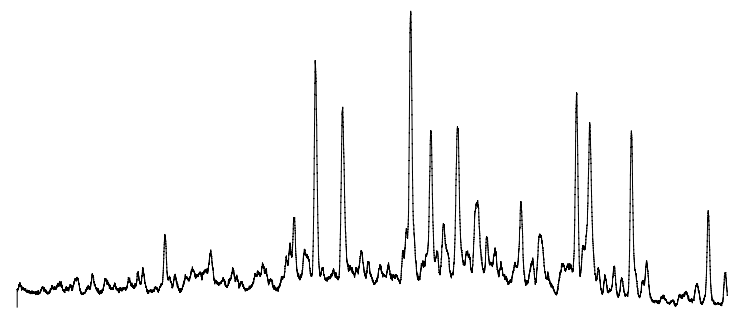

$\mathrm{m} / \mathrm{z}$ 217: Sterane for sample BH15B

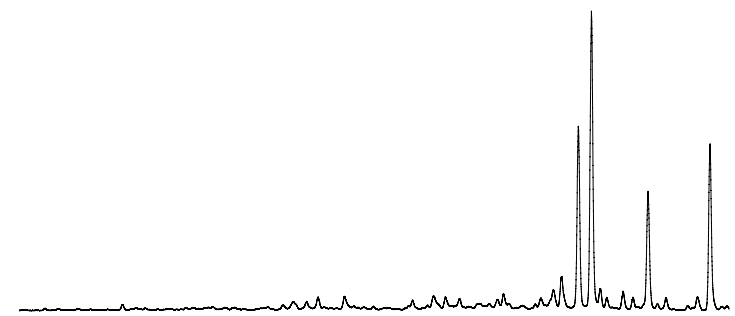

$\mathrm{m} / \mathrm{z} 218: \beta \beta$ Sterane for sample BH15B

\section{References}

Abubakar MB, Obaje NG, Luterbacher HP, Dike EFC, Ashraf AR (2006) A report on the occurrence of Albian-Cenomanian elaterbearing pollen in Nasara-1 well, upper Benue Trough, Nigeria. Biostratigraphic and palaeoclimatological implications. J Afr Earth Sci 45:347-354

Benkhelil J (1989) The origin and evolution of the cretaceous Benue Trough (Nigeria). J Afr Earth Sci 8:251-282. https://doi. org/10.1016/S0899-5362(89)80028-4

Clayton J, King J (1987) Effects of weathering on biological marker and aromatic hydrocarbon composition of organic matter in phosphoria shale outcrop. Geochim Cosmochim Acta 51:2153-2157

Clayton JL, Law EB (1993) Composition of crude oils generated from coals and coaly organic matter in shales. In: Rice, DD (ed) Hydrocarbons from coal, vol 38, American Association of Petroleum Geologist Studies in Geology, pp 185-201

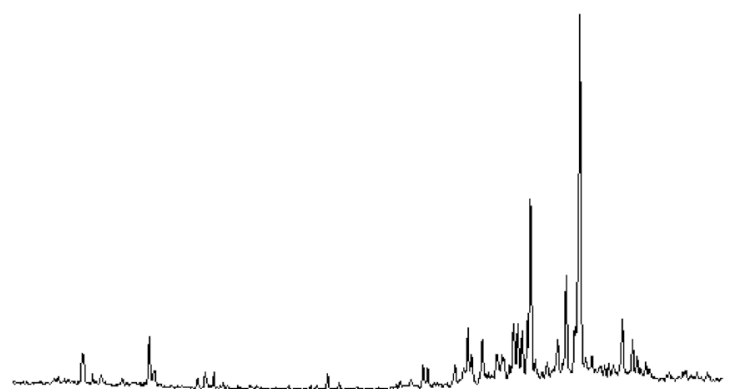

$m / z$ 253: Monoaromatic steroid for sample BH15B

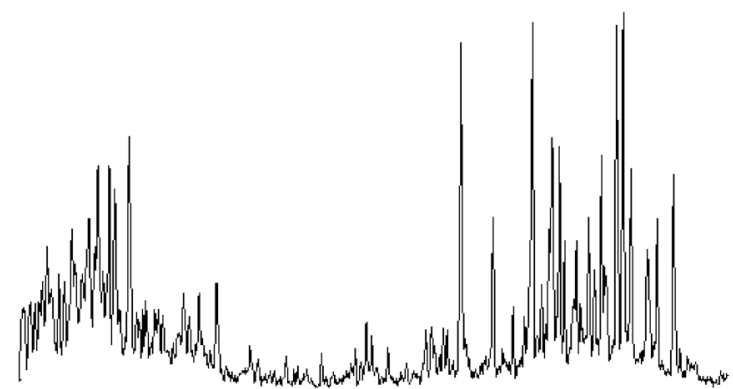

$m / z$ 231: Triaromatic steroid for sample BH15B

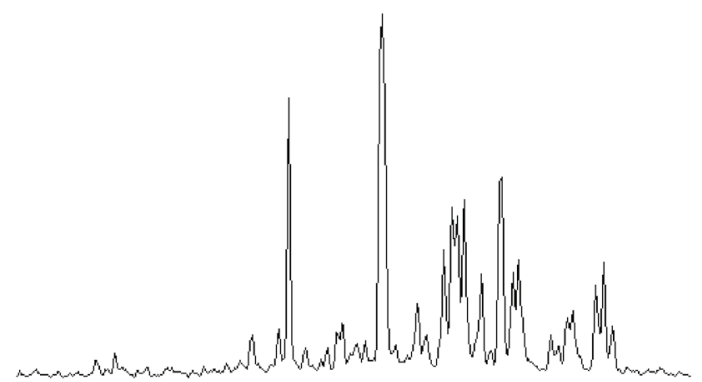

$m / z$ 245: Triaromatic methylsteroid for sample BH15B

Ficken KJ, Li B, Swain DL, Eglinton G (2000) An $n$-alkane proxy for the sedimentary input of submerged/floating fresh water aquatic macrophytes. Org Geochem 31(7-8):745-749

Hughes WB, Holba AG, Dzhou LIP (1995) The ratios of dibenzothiophene to phenanthrene and pristane to phytane as indicators of depositional environment and lithology of petroleum source rocks. Geochim Cosmochim Acta 59:3581-3598

Hunt JH (1991) Generation of gas and oil from coal and other terrestrial organic matter. Org Geochem 17(6):673-680

Hunt JH (1996a) Petroleum geochemistry and geology, 2nd edn. Freeman, New York, p 743

Hunt JM (1996b) Petroleum geochemistry and geology, 2nd edn. W.H. Freeman and Company, New York

Inaba T, Suzuki N, Hirai A, Sekiguchi K, Watanabe T (2001) Source rock lithology prediction based on oil diacholestane abundance in the siliceous-clastic Akita sedimentary basin, Japan. Org Geochem 32(7):877-890 
Isaksen GH, Curry DJ, Yeakel JD, Jensen AI (1998) Controls on the oil and gas potential of humic coals. Org Geochem 29:23-44

Jimoh AY, Ojo OJ (2016) Rock Eval pyrolysis and organic petrographic analysis of the Maastrichtian coals and shales at Gombe, Gongola Basin, Northeastern Nigeria. Arab J Geosci. https://doi. org/10.1007/s12517-016-2467-x.9:443

Killops SD, Killops VJ (1993) An introduction to organic geochemistry. Longman Group Ltd, UK

Killops SD, Killops VJ (2005) Introduction to organic geochemistry, 2nd edn. Blackwell Publishing Limited, UK

Langford FF, Blanc-Valleron MM (1990) Interpreting Rock Eval pyrolysis data using graphs of pyrolizable hydrocarbons versus total organic carbon. Am Assoc Pet Geol Bull 74:799-804

Lar UA, Bata TP, Dibal HU, Daspan RI, Isah LC, Fube AA, Bassi DA (2018) Field, petrographic and geochemical studies of basement, clastic and carbonate petroleum reservoirs in The Northern Benue Trough, Nigeria. Pet Technol Dev J 8(2):36-52

Lo H, Cardott B (1995) Detection of natural weathering of upper Mcalester coal and Woodford shale, Oklahoma, USA. Org Geochem 22:73-83

Miranda ACML, Loureiro MRB, Cardoso JN (1999) Aliphatic and Aromatic hydrocarbons in Candiota col samples: novel series of bicyclic compounds. Org Geochem 30:1027-1028

Moldowan JM, Seifert WK, Gallegos EJ (1985) Relationship between petroleum composition and depositional environment of petroleum source rocks. Am Assoc Pet Geol Bull 69:1255-1268

Mukhopadhyay PK, Hatcher PG (1993) Composition of coal. In: Law BE, Rice DD (eds) Hydrocarbons in coal, vol 38, American Association of Petroleum Geologists Studies in Geology, pp 79-118

Norgate CM, Boreham CJ, Wilkens AJ (1999) Changes in hydrocarbon maturity indices with coal rank and type, Buller Coalfield, New Zealand. Org Geochem 30(985):1010

Odebode MO (2010) A handout on the geology of the Benue and Anambra Basins, Nigeria. Unpublished

Olade MA (1975) Evolution of Nigerian Benue Trough (Aulacogen): a tectonic model. Geol Mag 112:575-583
Onoduku US, Okosun EA, Akande WG (2013) An assessment of the hydrocarbon potential of the Gombe Formation, upper Benue Trough, Northeastern Nigeria: organic geochemical point of view. Earth Sci Res 2(2):203-213

Peters KE, Moldowan JM (1993) The biomarker guide. Interpreting molecular fossils in petroleum and ancient sediments. Englewood Cliffs: New Jersey

Peters KE, Walters CC, Moldowan JM (2005) The biomarker guide, 2nd edn. Cambridge University Press, Cambridge

Petersen HI, Nytoft HP (2006) Oil generation capacity of coals as a function of coal age and aliphatic structure. Org Geochem 37:558-583

Seifert WK, Moldowan JM (1986) Use of biological markers in petroleum exploration. In: Johns RB (ed) Methods in geochemistry and geophysics, vol 24. Elsevier, Amsterdam, pp 261-290

Snowdon LR (1991) Oil from Type III organic matter: resinite revisited. Org Geochem 17:743-747

Tissot BP, Welte DH (1984) Petroleum formation and occurrence. Springer, Belin

Van Krevelen DW (1961) Coal: typology—chemistry—physics—constitution, 1st edn. Elsevier, Amsterdam, p 514

Wang P, Li M, Larter SR (1996) Extended hopanes beyond C40 in crude oils and source rocks extracts from Liaohe Basin, NE China. Org Geochem 24(5):547-551

Whiteman A (1982) Nigeria: its petroleum geology, resources and potential: London, Graham and Trotman, p 381

Wright JB (1968) South Atlantic continental drift and the Benue Trough. Tectono Phys 6:301-310

Publisher's Note Springer Nature remains neutral with regard to jurisdictional claims in published maps and institutional affiliations. 